\title{
MASTER
}

\section{ORNL Shielded Facilities Capable of Remote Handling of Highly Radioactive Beta-Gamma Emitting Materials}

\author{
W. R. Whitson
}

\section{OAK RIDGE NATIONAL LABORATORY}




\section{DISCLAIMER}

This report was prepared as an account of work sponsored by an agency of the United States Government. Neither the United States Government nor any agency Thereof, nor any of their employees, makes any warranty, express or implied, or assumes any legal liability or responsibility for the accuracy, completeness, or usefulness of any information, apparatus, product, or process disclosed, or represents that its use would not infringe privately owned rights. Reference herein to any specific commercial product, process, or service by trade name, trademark, manufacturer, or otherwise does not necessarily constitute or imply its endorsement, recommendation, or favoring by the United States Government or any agency thereof. The views and opinions of authors expressed herein do not necessarily state or reflect those of the United States Government or any agency thereof. 


\section{DISCLAIMER}

Portions of this document may be illegible in electronic image products. Images are produced from the best available original document. 


\section{Printed in the United States of America. Available from}

National Technical Information Service

U.S. Department of Commerce 5285 Port Royal Road, Springfield, Virginia 22161

Price: Printed Copy $\$$ Microfiche $\$ 3.00$

This report was prepared as an account of work sponsored by the United States Government. Neither the United States nor the Energy Research and Development Administration/United States Nuclear Regulatory Commission, nor any of their employees, nor any of their contractors, subcontractors, or their employees, makes any warranty, express or implied, or assumes any legal liability or responsibility for the accuracy, completeness or usefulness of any information, apparatus, product or process disclosed, or represents that its use would not infringe privately owned rights. 
ORNL/TM-5971

Contract No. W-7405-eng-26

\title{
ORNL SHIELDED FACILITIES CAPABLE OF REMOTE HANDLING OF HIGHLY RADIOACTIVE BETA-GAMMA EMITTING MATERIALS
}

\author{
W. R. Whitson \\ Pilot Plant Section \\ Chemical Technology Division
}

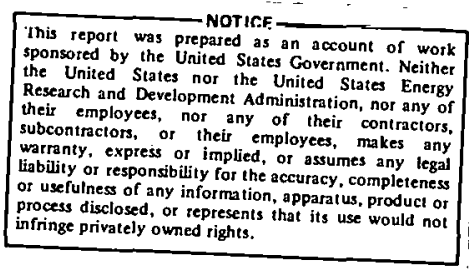

SEPTEMBER 1977

NOTICE This document contains information of a preliminary nature. It is subject to revision or correction and therefore does not represent a final report.

\author{
OAK RIDGE NATIONAL LABORATORY \\ Oak Ridge, Tennessee 37830 \\ operated by \\ UNION CARBIDE CORPORATION \\ for the \\ ENERGY RESEARCH AND DEVELOPMENT ADMINISTRATION
}




\section{THIS PAGE}

\section{WAS INTENTIONALLY \\ LEFT BLANK}


Table of Contents

Page

ABSTRACT . . . . . . . . . . . . . . . . . . . 1

1. INTRODUCTION . . . . . . . . . . . . . . . . 1

2. BLDG. 3026 - HIGH RADIATION-LEVEL ANALYTICAL LABORATORY

$($ HRLAL) .. . ....................... 1

Description ...................... 1

Capability ...................... . 3

Availability .................. . . 3

3. BLDG. 3019 HIGH RADIATION-LEVEL ANALYTICAL FACILITY (HRLAF). 4 Description .................... 4

Capability ..................... 4

Experience ...................... 4

4. BLDG. 3019 RADIOCHEMICAL PROCESSING PILOT PLANT (RPPP) . . . 6

Description .................... 6

Capability....................... 6

Experience ..................... 9

5. Bldg. 3025 HOT CELLS ................. . . 9

Description ................... . . 9

Capability.................... 11

6. BLDG. 3026D - SEGMENTING CELLS . . . . . . . . . . 11

Description ...................... 11

Capability . . . . . . . . . . . . . . . 13

Experience ..................... 13

7. BLDG. $3028 E$ - CURIUM SOURCE FABRICATION FACILITY (CSFF). . . 13

Description ................. . . 13

Experience ..................... 13

8. BLDG. 3029 - SOURCE DEVELOPMENT LABORATORY (SDL) . . . . . . 15

Description .................... 15

Capability ................... 15

Experience ..................... 15

9. BLDG. 3047 - RADIOISOTOPE DEVELOPMENT LABORATORY (RDL) . . 18

Description ................... 18

Cababilitv....................... 18 
10. BLDG. 3517 - FISSION PRODUCTS DEVELOPMENT LABORATORY (FPDL) 22

Description ................ 22

Capability .................. 22

Experience ................... 22

11. BLDG. 3525 - HIGH-RADIATION-LEVEL EXAMINATION LABORATORY

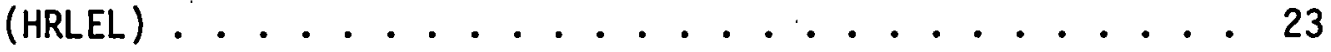

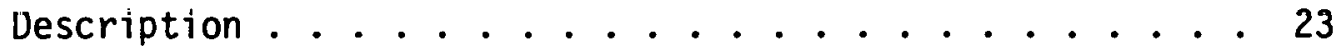

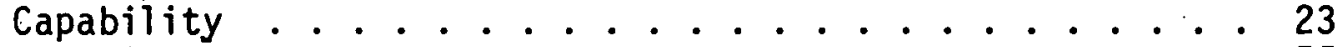

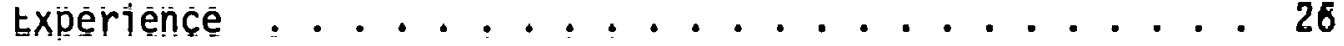

12. BLDG. 4501 - HOT CELLS . . . . . . . . . 26

Description ................ . 26

Capability .................. . 26

[xperience ...................... 29

13. BLDG. 4507 - HIGH RADIATION-LEVEL CHEMICAL DEVELOPMENT

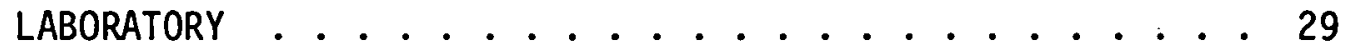

Description ................ . . 29

Capability ................ 29

Expertence ...................... 31

14. BLDG. 7920 - TRANSURANIUM PROCESSING PLANT (TRU) . . . . 31

Description ................ . . 31

Capability .................. 31

Experience ...................... 34

15. BLDG. 7930 - THORIUM-URANIUM FUEL CYCLE DEVELOPMENT

FACILITY (TURF) ................. 34

Deseription ................ . . 34

Capability .................. . . . 37

Experience ............... . . 37 
ORNL SHIELDED FACILITIES CAPABLE OF REMOTE HANDLING OF HIGHLY RADIOACTIVE BETA-GAMMA EMITTING MATERIALS

\author{
W. R. WHITSON
}

ABSTRACT

This report summarizes a survey made of ORNL facilities having adequate shielding and containment for the remote handling of experimental quantities of highly radioactive betagamma emitting materials. Portions of the detailed descriptions of these facilities previously published in ORNL/TM-1268 are still valid and are repeated.

\title{
1. INTRODUCTION
}

The present status of the ORNL research facilities listed in ORNL/TM1268 (published in 1965) was reviewed relative to the ability of these facilities to handle highly irradiated materials containing plutonium and other high-alpha materials.

Those facilities lacking adequate shielding from beta-gamma radiation were not considered in this review.

The following eight facilities have sufficient shielding and containment for the handling of highly irradiated alpha materials: B1dgs. 2026 (HRLAL), 3019 (RPPP), 3026D (Segmenting. Cel1s), 3047 (RDL), 3525 (HRLEL), 4507,7920 (TRU), and 7930 (TURF). The following six facilities have adequate shielding but lack sufficient containment for handling plutonium and other highly irradiated alpha materials: Bldgs. 3019 (HRLAF), 3025, $3028 E$ (CSFF), 3029 (SDL), 3517 (FPDL), and 4501 (Hot Cells). A brief description of these facilities, along with their capabilities and some of their experiences, is summarized.

\section{BLDG. 3026 - HIGH RADIATION-LEVEL ANALYTICAL LABORATORY (HRLAL) \\ Description}

The building has two levels and is constructed of concrete blocks and poured concrete. The gross floor area is approximately $22,000 \mathrm{ft}^{2}$ including the hot-cell block and scrubber pits. The in-a-line hot-cell bank is centrally located and is surrounded by auxiliary areas (Fig. 1). 


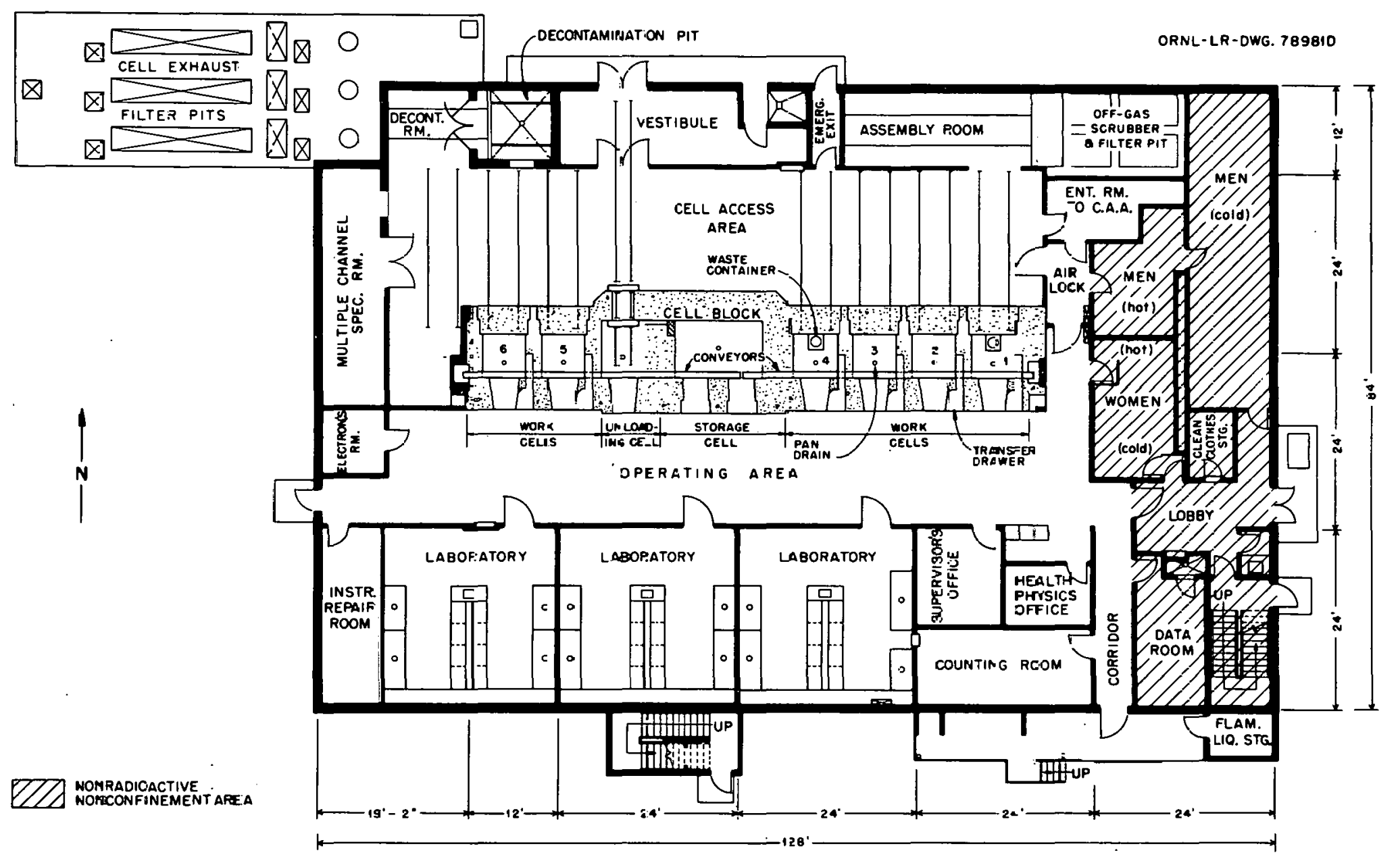

$N$

Fig. 1. First floor plan of High Radiation Level Analytical Laboratory. 
The auxiliary areas include offices, laboratories, and individual rooms for conferences, equipment assembly, equipment decontamination, heating and ventilation control equipment, clothing change, and chemical and equipment storage.

The hot-cell bank has six work cells, a sample-carrier unloading cell, and a sample storage cell. Exterior walls of high-density concrete in the sample storage cell and of normal concrete in the work cells provide shielding for 25,000 and $1400 \mathrm{Ci}$ of ${ }^{60} \mathrm{Co}$, respectively, with a radiation level at the outer surface $<1 \mathrm{mR} / \mathrm{hr}$. The windows in the storage cell are lead glass; those in the work cells and unloading cell contain a zinc bromide solution. Each cell is equipped with standard-duty AMF Model 8 masterslave manipulators, an intercell conveyor, standard services, mercury-vapor and incandescent lights, and sleeves for cables and tubes. The work cells have, in addition, a transfer drawer and a roll-out pan for supporting the analytical equipment.

\section{Capability}

The facility is designed for the treatment and chemical analysis of highly radioactive beta- and gamma-emitting materials. Samples containing plutonium can be accepted for analysis, subject to review and approval. The facility is approved for solutions or solids containing up to $350 \mathrm{~g}$ of plutonium in the storage cell and up to $10 \mathrm{~g}$ of plutonium in a work cell. Equipment is available for nuclear energy measurements by alpha and gamma spectrometry, ionic determinations, radiochemical separations and analysis, and preparation of samples for isotopic measurcment.

\section{Availability}

All cells are presently in use. The Light-Water Reactor (LWR) development work is being conducted in Cell 5. The remaining five cells are used for analyses of the samples which various programs and projects submit on a routine basis. Some cells could be made available, however, if an urgent need with high priority arose. 
3. BLDG. 3019 HIGH RADIATION-LEVEL ANALYTICAL FACILITY (HRLAF)

Description

The HRLAF cell bank has seven working cells and a storage/unloading cell (see Fig. 2). Shielding is provided by high-density concrete walls $3 \mathrm{ft}$ thick with cerium-stabilized glass windows filled with a zinc bromide solution. Samples are transferred between cells by two intercell conveyors; samples are also transferred to and from the cells in the operating area by means of two small sliding drawers contained in a stainless steel duct. A large concrete door behind each cell permits entrance for decontamination and maintenance. Each cell has two Model 8 AMF manipulators.

Capability

Limited amounts of plutonium and high-alpha materials can be handled only with the approval of the Radioactive Operations Committee (ROC) for each application. Although the facility was originally approved for handling $100 \mathrm{~g}$ of plutonium in solution in the storage cell and $10 \mathrm{~g}$ of plutonium in solution in one of the two cells modified for high-alpha materials, the containment and ventilation systems do not meet the present requirements for handling gram quantities of plutonium and other alphasource materials.

A proposal to upgrade the cell bank has been submitted and, if approved, will probably handle the anticipated sample load generated by the Hot Engineering Test work associated with the High Temperature GasCooled Reactor (HTGR) Program.

\section{Experience}

Many highly radioactive solutions containing several milligrams per milliter of plutonium, americium, and curium have been analyzed; the two modified work cells have analyzed curium solutions at up to $10^{13} \mathrm{dpm}$ alpha activity.

Cells 4 and 6 are used exclusively for spectrographic analyses, and Cell 5 is used for weighing samples. Cell 3 is equipped for radial sectioning of the sleeves and spines from dismantled Peach Bottom Reactor fuel elements in preparation for analyses. The limited work that is done occasionally in the other cells could easily be conducted elsewhere. 
ORNL-DWG . 74-5163

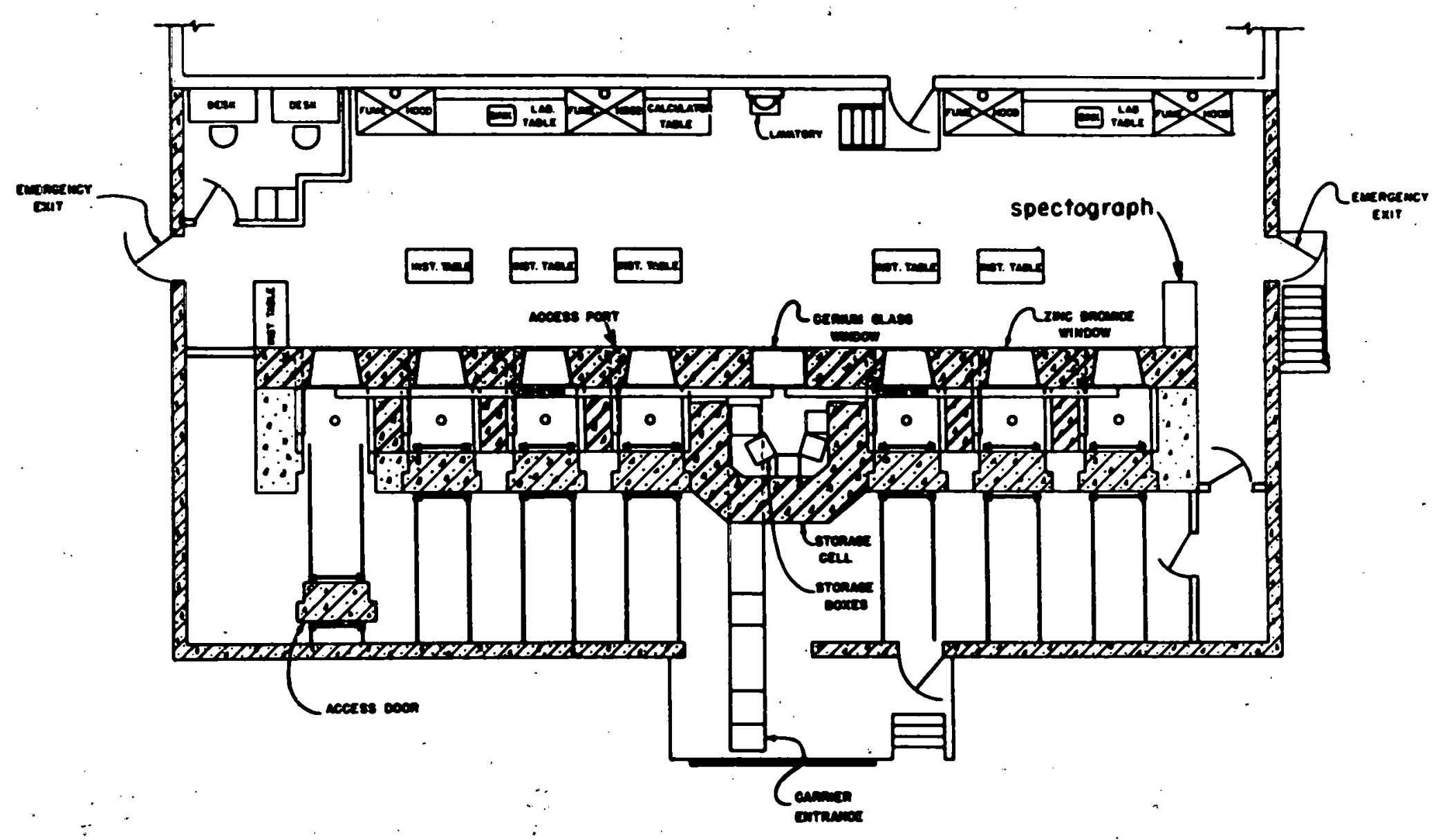

Fig. 2. Plan of High Radiation Level Analytical Facility. 


\section{BLDG. 3019 RADIOCHEMICAL PROCESSING PILOT PLANT (RPPP) Description}

The Radiochemical Processing Pilot Plant (RPPP) occuptes the eastern two-thirds of Bldg. 3019. It comprises an area of approximately $20,000 \mathrm{ft}^{2}$, including an operating hot cell bank and auxillary support areas (Fig. 3). The hot-cell bank has a row of seven cells, each $20 \mathrm{ft}$ by $20 \mathrm{ft}$ by $27 \mathrm{ft}$ high, constructed of reinforced barytes concrete $5 \mathrm{ft}$ thick on three sides and $4 \mathrm{ft}$ thick on one side and the top (Fig. 4). Removable celling plugs ( $9 \mathrm{ft}$ b.y $9 \mathrm{ft}$ ) permit access to the cells from the penthouse area. A 10-ton bridge crane that can travel the length $(165 \mathrm{ft}$ ) of the penthouse serves to move equipment and materials to and from the cells; personnel enter the cells through a shielded passageway to the floor level of each cell.

The auxilary facilities include offices, maintenance shops, change rooms, a Health Physics facility, a lunchroom, and the off-gas stack, filter, and fan system. The facility also houses two well-contained alpha laboratories (Rooms 211 and 303A) that meet all requirements for hand ling plutonium and other high-alpha materials; Room 502 contains equipment in high-quality glove boxes to convert ${ }^{233} \mathrm{UNH}$ to ceramic-grade ${ }^{233} \mathrm{UO}_{2}$ at a rate of $6 \mathrm{~kg}$ per day.

Three separate ventilation systems serve Bldg. 3019. The main system discharges all cell ventilation air to the 3020 stack; all alpha glove boxes are exhausted to the High-Alpha Ventilation system that was installed tor ": the LWBR program, and all process vessels are vented through the Vessel Off-Gas system to the 3039 stack. Each system has electrically operated fans with a standby steam-operated fan that functions automatically during an electrical power failure. Each system has absolute filters.

The present safeguards system is undergoing major modifications which, when completed, will meet all the ERDA criteria for safeguards.

\section{Capability}

The farility is equipped with liquid storage vessels having a capacity of $900 \mathrm{~kg}$ of $233 \mathrm{U}$ and solids storage wells with a capacity of $1500 \mathrm{~kg}$ of ${ }^{233} \mathrm{U}$ (density of $3.5 \mathrm{~g} / \mathrm{cm}^{3}$ ). An additional solids storage facility with a capacity of $22000 \mathrm{~kg}$ of uranium is being designed for installation in 


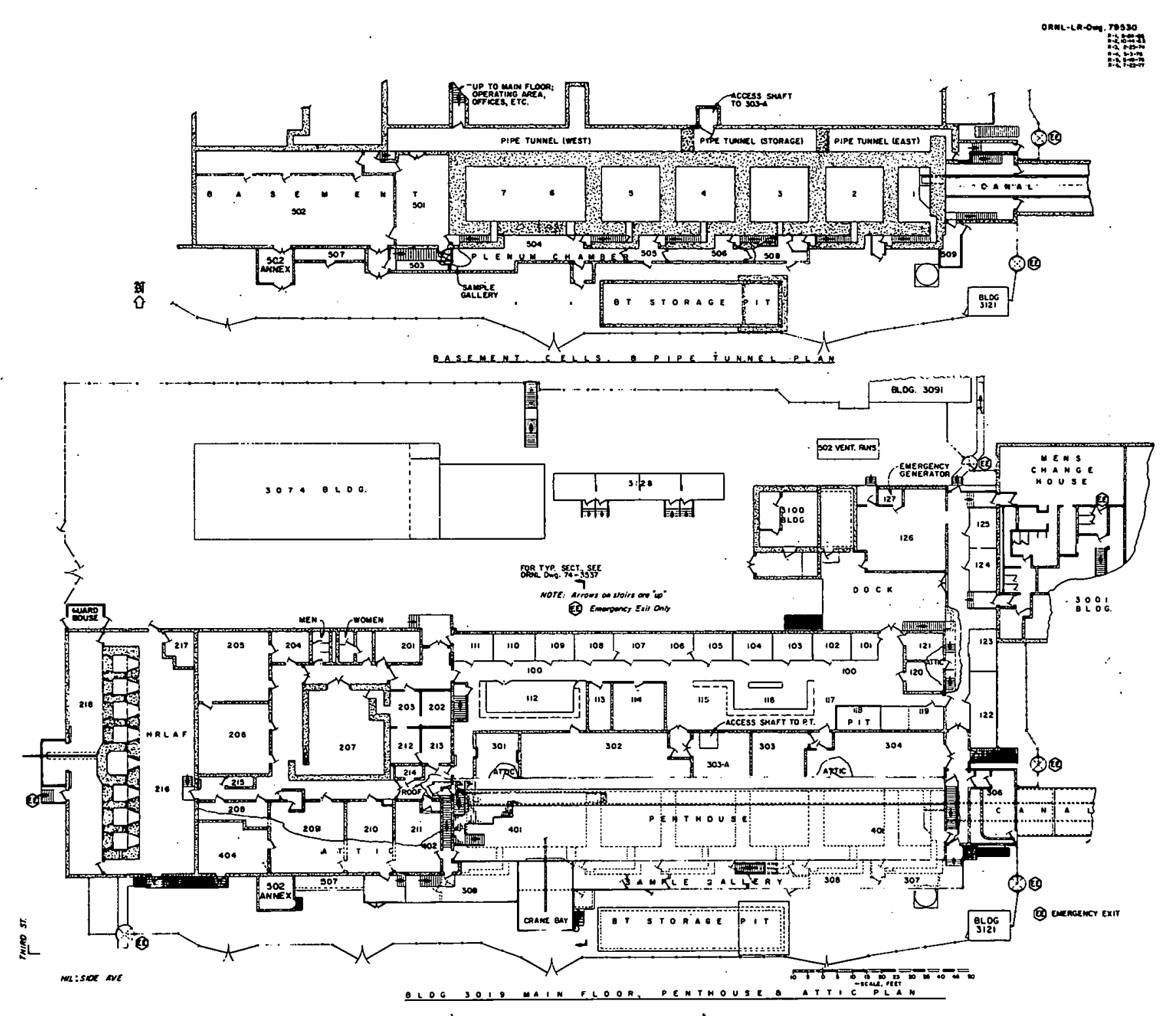

Fig. 3. Plan of Building 3019 Radiochemical Processing Pilot Plant. 


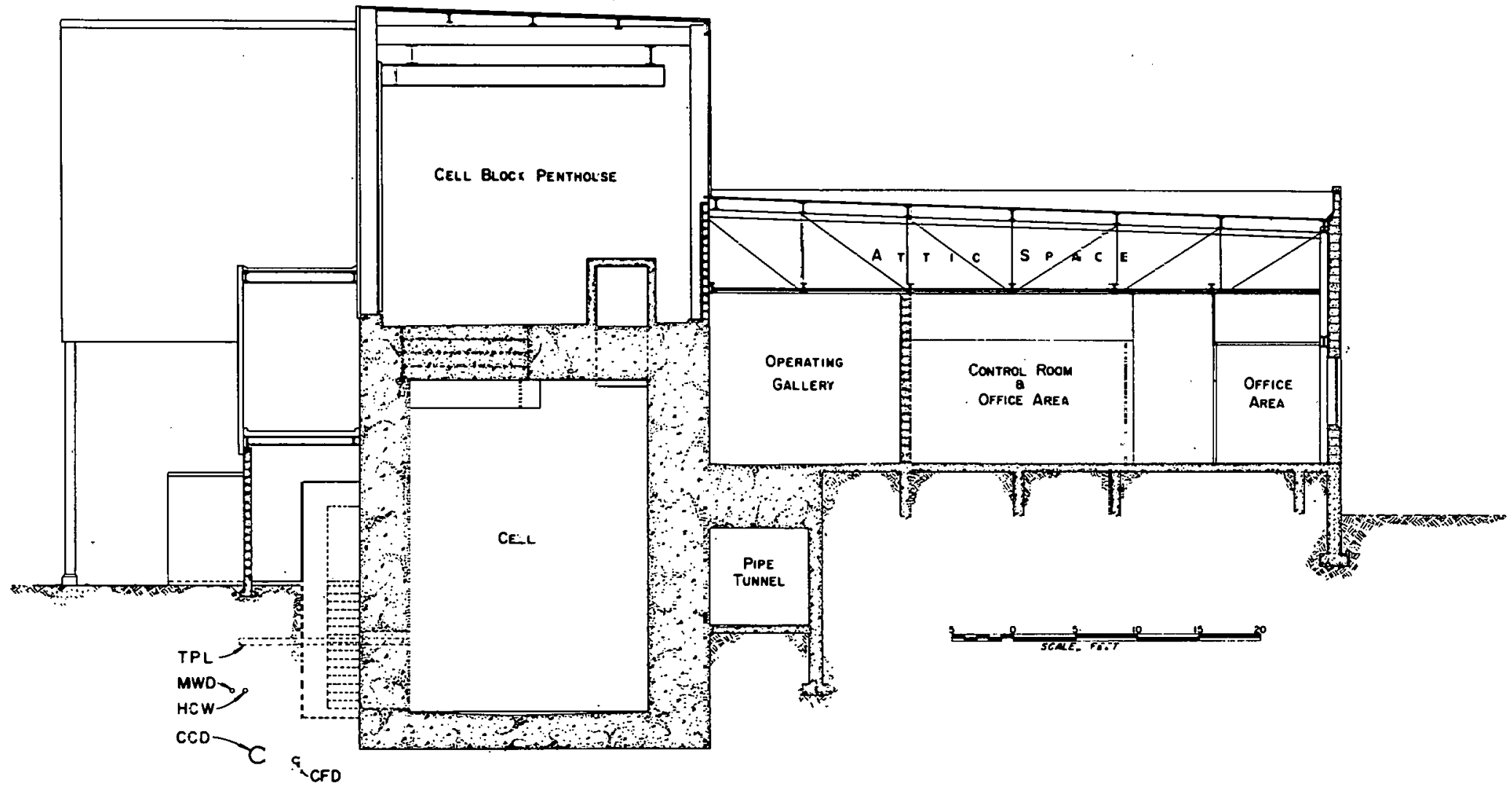

Fig. 4. Cross section of Building 3019. 
Cell 4. Approximately one-half of this facility will store the Con Ed uranium (TRUST) which will be converted from a nitrate solution to $\mathrm{UO}_{3}$ powder in a processing facility to be installed in Cell 3. Remotely operated processing equipment for a single cycle solvent-extraction purification system, a high pressure ion-exchange system, and three dissolvers occupy Cells 5,6, and 7. Two dissolvers handle $\mathrm{UO}_{2}-\mathrm{ThO}_{2}$ scrap and the third pure $\mathrm{UO}_{2}$ powder. Presently, Cells 1 and 2 are not being used. However, a proposal to install an engineering-scale demonstration for the remote fabrication of $233 \mathrm{U}-\mathrm{Th}$ sphere pac fuels for fast breeder reactors has been submitted.

\section{Experience}

Many separation and purification programs have been completed in the RPPP. The separation of plutonium and uranium by the bismuth phosphate process was demonstrated successfully in 1944. Since then, the Purex process, Thorex process, the Fluoride Volatility program, and the Kilorod program have been completed. In a campaign just concluded, a total of $1610 \mathrm{~kg}$ of ${ }^{233} \mathrm{U}$ was converted from ${ }^{233} \mathrm{UNH}$ to ceramic-grade $233_{\mathrm{UO}_{2}}$ of high purity for the LWBR program. The BIdg. 3019 RPPP has served since 1962 as a national repository and distribution center for ${ }^{233} \mathrm{U}$.

\section{BLDG. 3025 HOT CELLS}

\section{Description}

The facility has six cells with a total of $330 \mathrm{ft}^{2}$ of floor space (Fig. 5). The cells are shielded with $3 \mathrm{ft}$ of high-density concrete and have zinc bromide viewing windows; exhaust is through absolute filters.

The first three cells are each about $11 \mathrm{ft}$ wide by $7 \mathrm{ft}$ deep by $11 \mathrm{ft}$ high; the floors are stainless steel, and the concrete walls are painted. Each cell has two windows with two master-slave manipulators at each window, and a GM manipulator serves the three cells. The next two cells have painted concrete walls and floors. Cell 4 is about $7 \mathrm{ft}$ wide by $5 \mathrm{ft}$ deep by $81 / 2 \mathrm{ft}$ high, and Cell 5 is about $3 \mathrm{ft}$ wide by $4 \mathrm{ft}$ deep by $71 / 2 \mathrm{ft}$ high; the cells are equipped with master-slave manipulators. The sixth cell is about $10 \mathrm{ft}$ wide by $5 \mathrm{ft}$ deep by $13 \mathrm{ft}$ high, and the floor and 


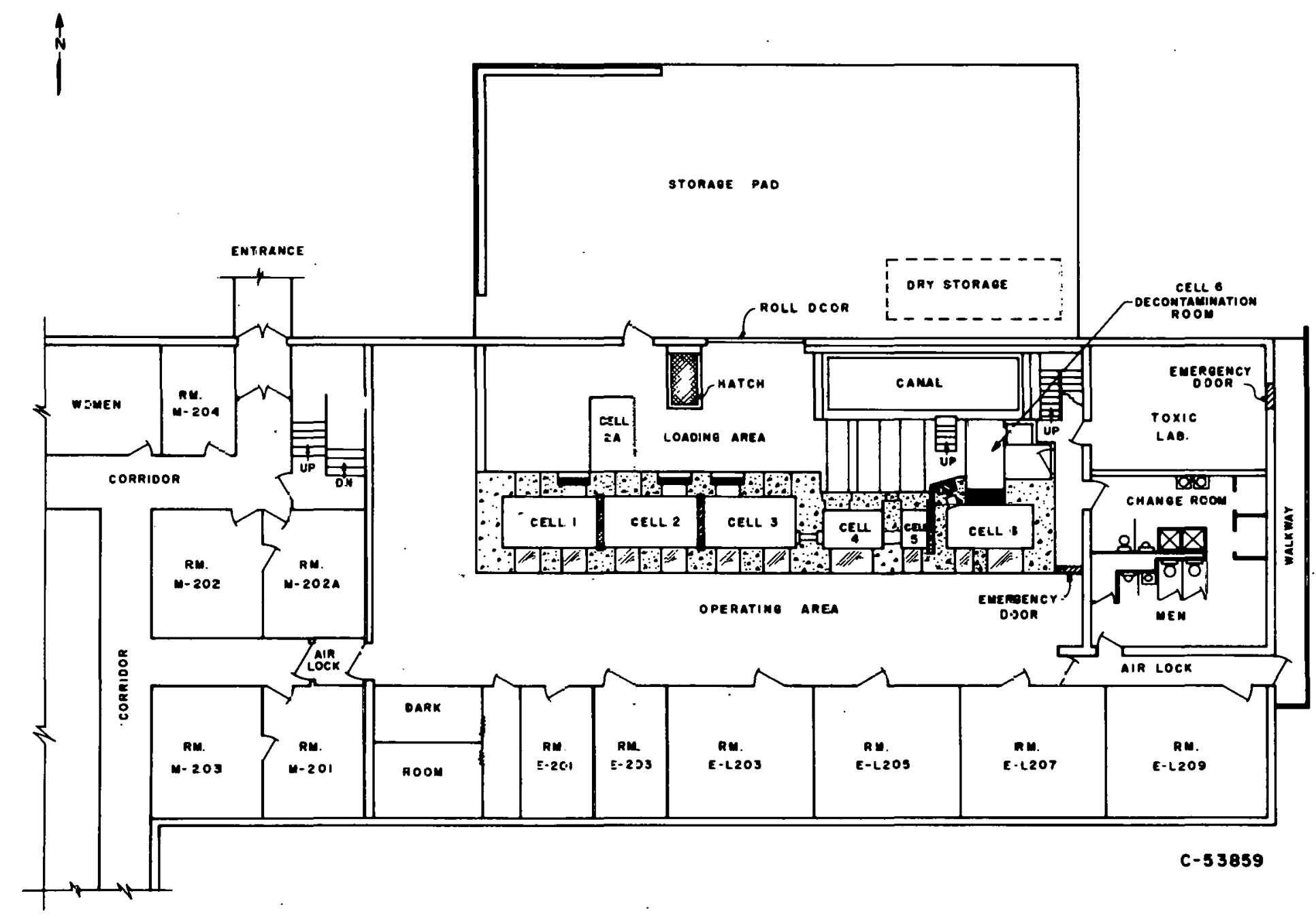

Fig. 5. Plan of Building 3025 hot cell area. 
walls are lined with stainless steel. It is equipped with three masterslave manipulators and a 7 -ton in-cell bridge crane.

\section{Capability}

The facility is used mainly for mechanical property testing of irradiated materials; included are creep, tensile, impact, bend, and tube-burst testing. The first cell contains a total of 11 creep-test machines which operate continuously with samples of stainless steel, aluminum, INOR-8, and other materials. Cell 2 contains an Instron tensile test machine for tensile and bend testing. Cell 3 has a pendulum-type impact-test machine for testing at liquid $\mathrm{N}_{2}$ temperatures to $250^{\circ} \mathrm{C}$. Cell 4 is prepared for installation of a MTS (mechanical property testing) machine in August 1977. Cell 5 is used for measurement and photography of the broken test specimens. Cell 6 is a general-purpose cell equipped with an abrasive wheel saw for sectioning, and a magnifying periscope with photographic attachments; other equipment can be installed as needed. The cell is presently used largely for the postirradiation disassembly of experiments containing metal specimens for mechanical property testing.

\section{BLDG. 3026D - SEGMENTING CELLS}

\section{Description}

The facility has three cells with a total floor space of $410 \mathrm{ft}^{2}$, the largest cell being $25 \mathrm{ft}$ wide by $10 \mathrm{ft}$ deep by $15 \mathrm{ft}$ high (see Fig. 6). The cell is shielded by $5 \mathrm{ft}$ of normal concrete with zinc bromide viewing windows; there are three windows in the large cell and one in each of the other cells. All of the cells have two master-slave manipulators at each window. Each of the two smaller cells has a 1-ton bridge crane, and the larger cell has an electromechanical manipulator and a 3-ton bridge crane. The walls and floor of the cells are lined with stainless steel, and the cells have HEPA filters in the exhaust system.

The large cell is equipped with a $\mathrm{CO}_{2}$ fire protection system. The cells contain disassembly and cutting equipment such as hacksaws, abrasive saws, a guillotine saw, and a magnifying perioscope for viewing and photography. An Instron machine has been installed for tensile and bend tests, and a shadowgraph has been included for precise dimensional measurements. Other equipment can be installed as needed. 
$1^{N}$

ORin Owa co-or24

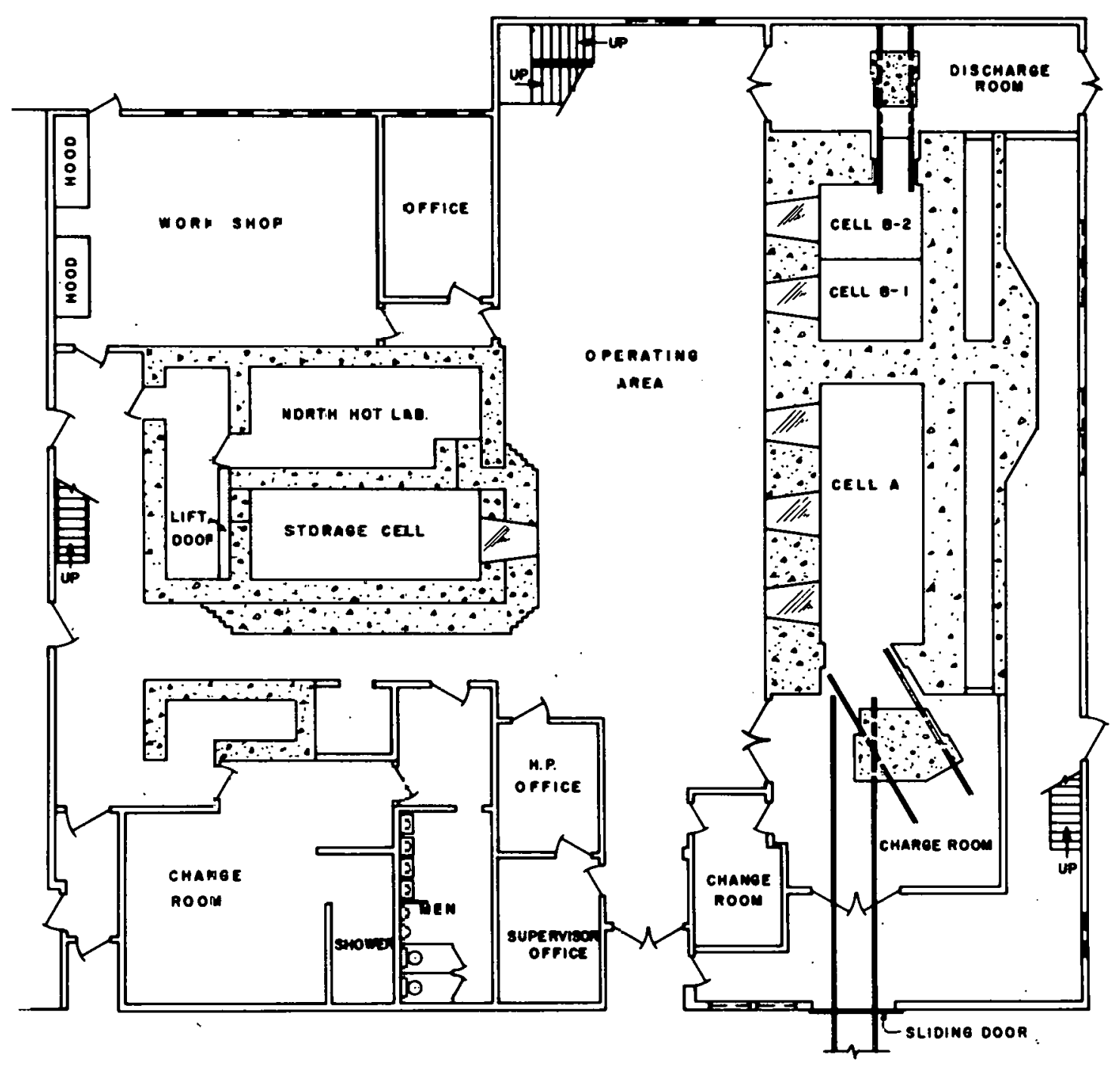

Fig. 6. Plan of Building 30260 hot cell area. 


\section{Capability}

The facility is used for the postirradiation experiments and mechanical disassembly of nuclear fuel elements up to $20 \mathrm{ft}$ long and $20 \mathrm{in}$. in diameter. Some tests (tensile, bend, dimensional measurements, and others) are made, but most of the experiment parts are transferred to other cells for detailed examination.

Quantities of plutonium limited only by criticality can be handled if the material has a sufficiently high gamma-to-alpha ratio. Operations are limited to mechanical disassembly when more than a few grams of plutonium are involved (i.e., no cutting or grinding of fueled sections).

\section{Experience}

Large capsules and loop sections are routinely disassembled. A failed fuel element from the Boiling Nuclear Superheat reactor (BONUS) and 25 irradiated Savannah River Experimental Reactor (SRE) fuel elements were mechanically disassembled. Peach Bottom Reactor fuel elements are periodically disassembled and examined. Routine destructive testing is performed on tensile specimens from irradiated structural materials. Occasionally, high-alpha materials are transferred from one container to another for a customer, but no chemical development work is done.

\section{BLDG. 3028E - CURIUM SOURCE FABRICATION FACILITY (CSFF)}

\section{Description}

The facility consists of five manipulator cells and an off-gas cleanup cell. A stainless steel-lined cell ( $5 \mathrm{ft} \times 8 \mathrm{ft}$ by $12 \mathrm{ft}$ interior) was modified by adding $1 \mathrm{ft}$ of concrete to the existing 9 in. of armor-plate shielding and altering the door to prevent the escape of alpha-activity (see Fig. 7).

Equipment is installed for precipitation, filtration, decantation, evaporation, dissolution, calcination, pelletization, sintering, and encapsulation by welding.

\section{Experience}

Multigram quantities of ${ }^{241} \mathrm{Am}$ and ${ }^{242} \mathrm{Cm}$ have been processed. Gram quantities of ${ }^{244} \mathrm{Cm}$ oxide have been packaged for customers. 


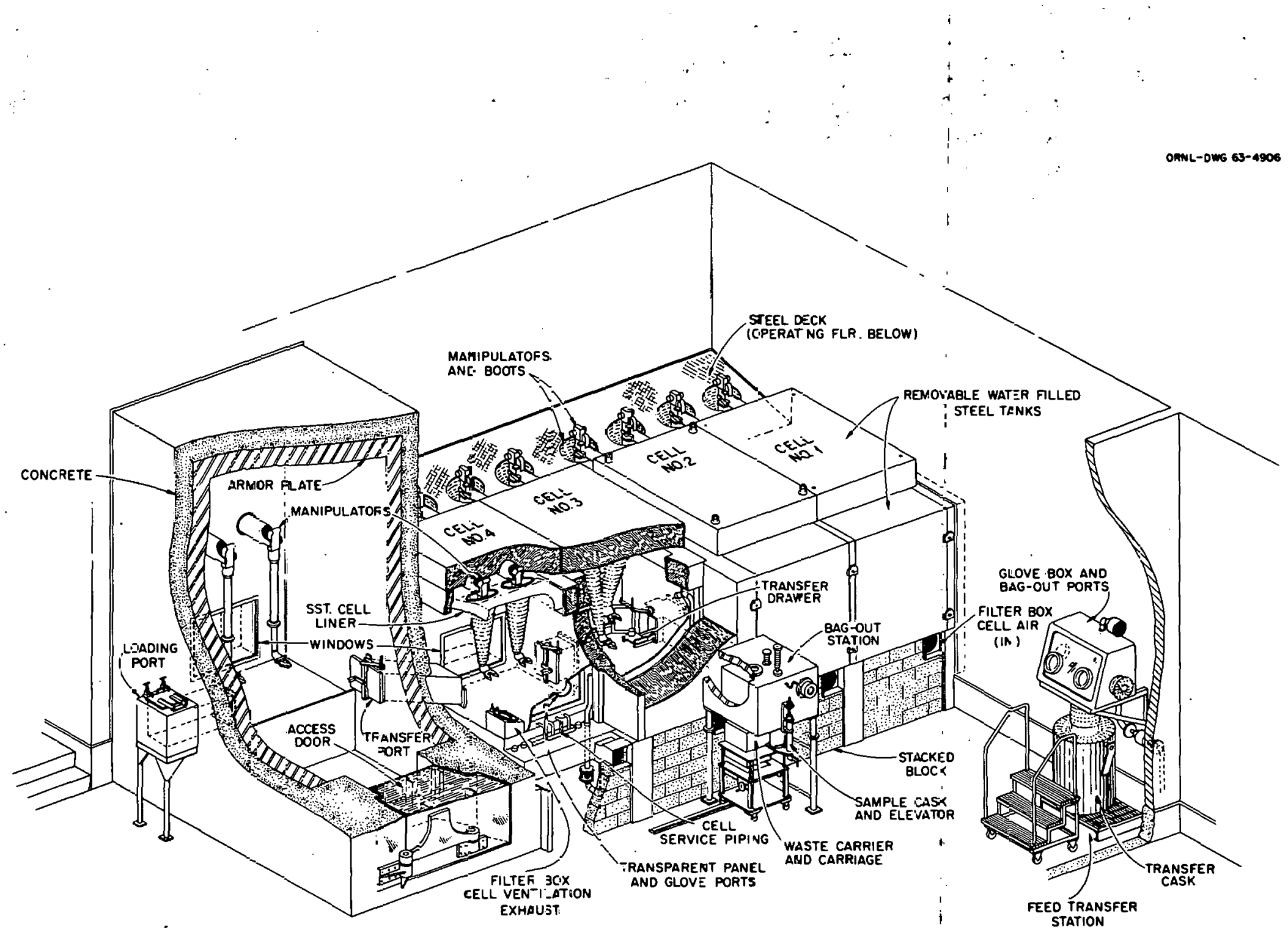

Fig. 7. Isometric section of Curium Source Fabrication Facility in Building 3028. 


\section{BLDG. 3029 - SOURCE DEVELOPMENT LABORATORY (SDL)}

Description

The SDL has four manipulator-equipped cells, three of which are used for high-level activity materials and one for chemical processing of lowlevel materials (Figs. 8 and 9). Two cells ( 1 and 3 ) have stainless steel liners and $3 \mathrm{ft}$ of barytes concrete for shielding; Cell 3 has an additional 2 in. of lead shielding. Cell 2 has a stainless steel operating pan and walls painted with a radiation-resistant sealant. The front side has $3 \mathrm{ft}$ of barytes concrete, and the rear has an 8-in. thick armor plate door that is hinged and operated manually. Cells 1 and 3 have motor-operated sliding doors of 3-ft barytes concrete at the rear. Each cell is equipped with two Model 8 AMF manipulators.

Secondary containment is provided by the building, which is a steel frame structure covered with corrugated aluminum siding that has been sealed as airtight as possible by cocooning the exterior surfaces.

\section{Capability}

These cells are used in the radioisotope production program. The facility is capable of developing chemical processes for reactor-produced isotopes and of developing fabrication, encapsulation, and quality control techniques for radioactive materials.

\section{Experience}

Kilocurie quantities of ${ }^{60} \mathrm{Co},{ }^{90} \mathrm{Sr},{ }^{137} \mathrm{Cs}$ have been handled. The facility has also prepared small amounts of elemental and methyl ${ }^{131}$ I. Other radioactive materials are handled as the need arises.

The cells 1 and 3 are not presently committed and could be used for plutonium work, with sufficient modifications to meet present alphacontainment standards. The large sliding doors at the rear of the cells would need replacing. 


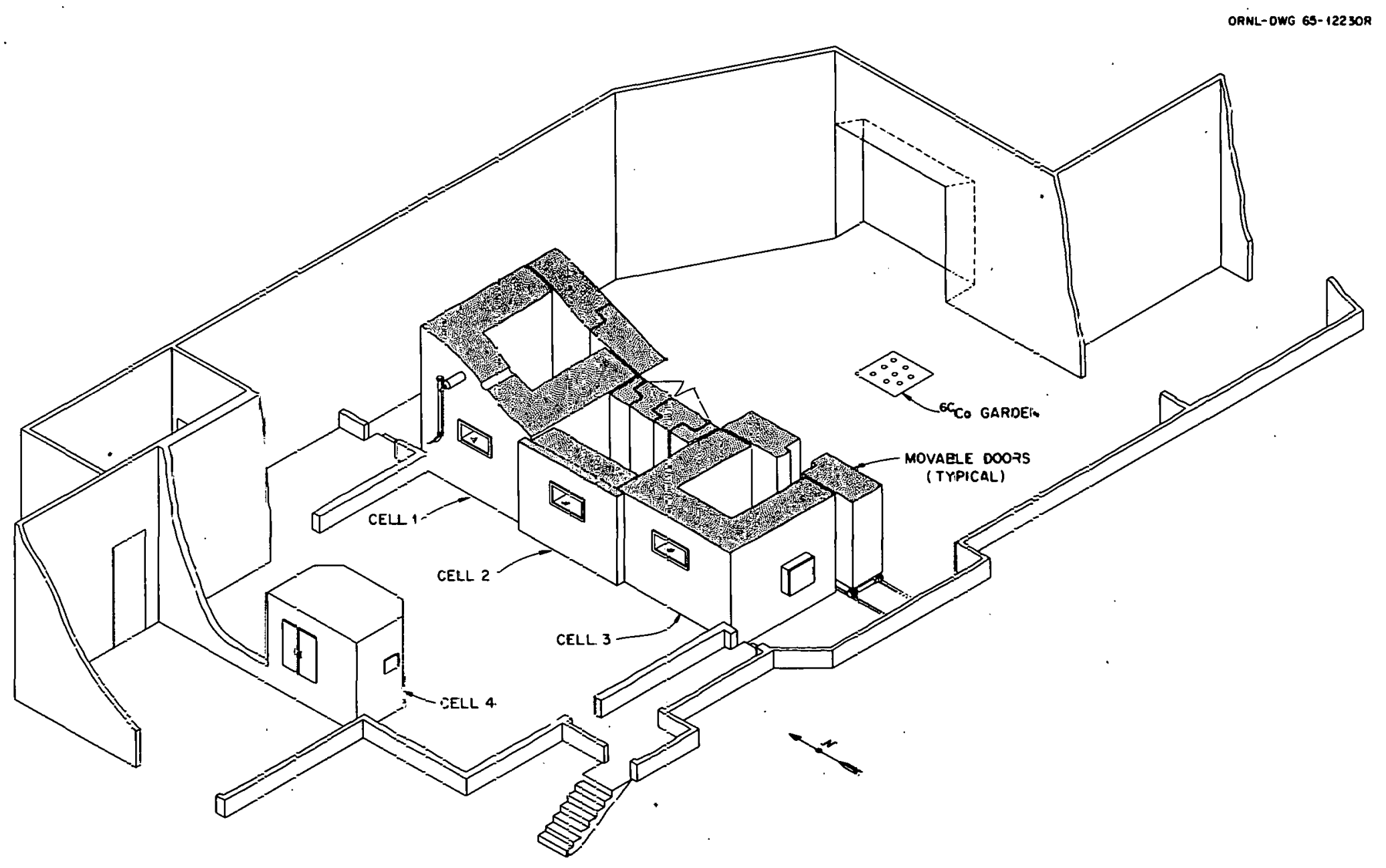

Fig. 8. Isonetric section of Building 3029 manipulator cells. 


$$
\text { 政 }
$$


9. BLDG. 3047 - RADIOISOTOPE DEVELOPMENT LABORATORY (RDL)

Description

The RDL has four stainless steel-lined manipulator cells $6 \mathrm{ft}$ wide, $8 \mathrm{ft}$ deep, and $13 \mathrm{ft}$ high (Figs. 10 and 11 ). Three of the cells have the equivalent of $4.4 \mathrm{ft}$ of standard concrete, and the other has the equivalent of $5.9 \mathrm{ft}$ of standard concrete for shielding. The cells have lead-glass windows with shielding equal to that of the walls. Each cell exhausts through dual HEPA filters. The cell bank, cell-operating and access areas, three hot laboratories on the second floor, and a decontamination room meet the maximum containment criteria.

\section{Capability}

Chemical processes such as solvent extraction, ion exchange, precipitation, and distillations are conducted in the cells, with equipment varying from ordinary glassware to multigallon stainless steel process equipment. Calcination, pelletization, and encapsulation process are also done in the facility. Mechanical testing and examinations are carried out. No more than $500 \mathrm{~g}$ of ${ }^{235} \mathrm{U}$ and $10 \mathrm{~g}$ of ${ }^{239} \mathrm{Pu}$ are permitted in the building at any one time.

All cells are committed for more than two years to isotope development programs and could become available only if certain programs. are cancelled.

\section{Experience}

Kilocuries quantities of ${ }^{60} \mathrm{Co},{ }^{90} \mathrm{Sr},{ }^{137} \mathrm{Cs},{ }^{152} \mathrm{Cu},{ }^{154} \mathrm{Eu}$, and ${ }^{244} \mathrm{Cm}$ and multicurie quantities of ${ }^{33} \mathrm{P},{ }^{43} \mathrm{~K}$, and ${ }^{153} \mathrm{Gd}$ have been processed in the facilities. 
ORNL DWG 64-8723AR
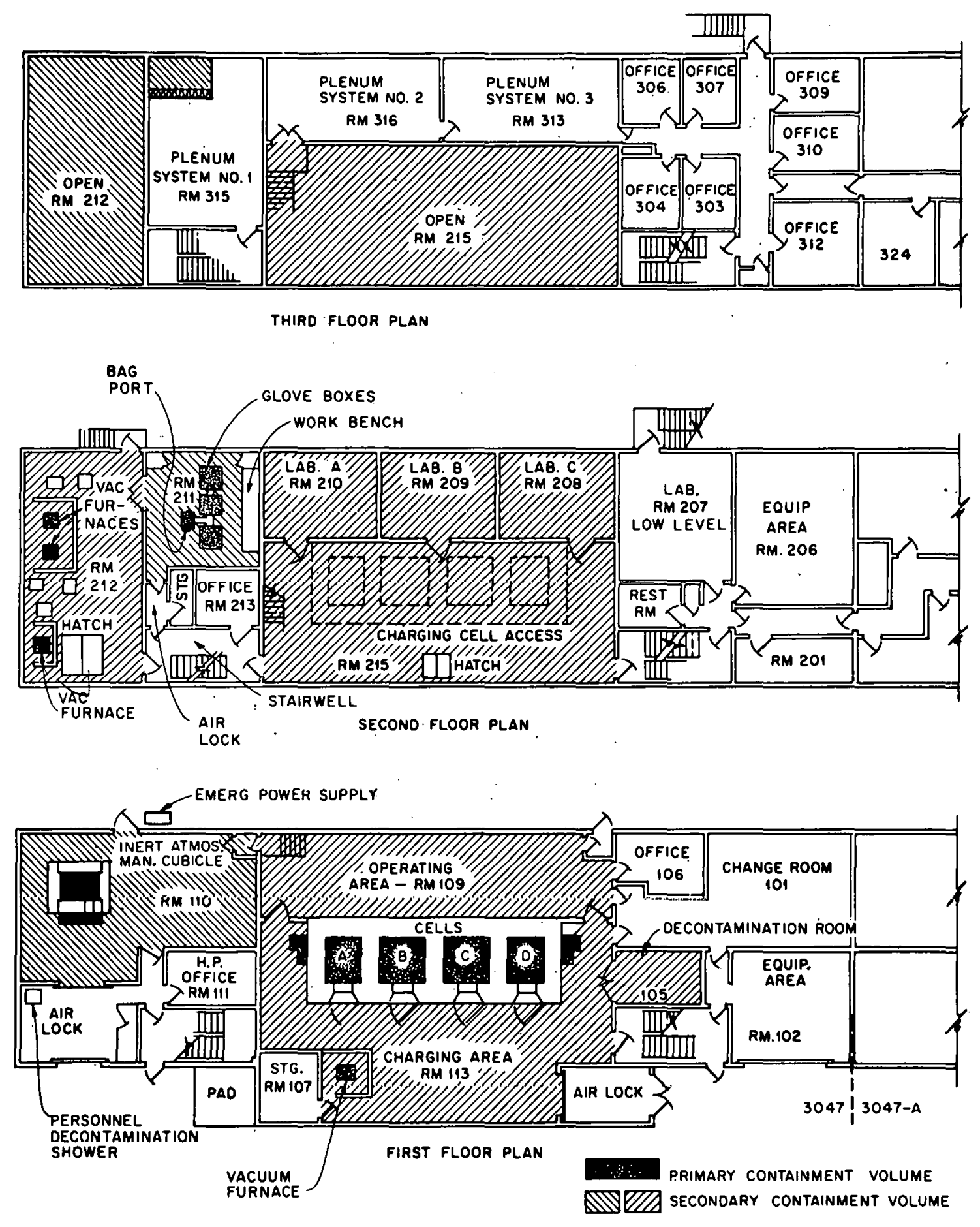

Fig. 10. Plan of Building 3047. 


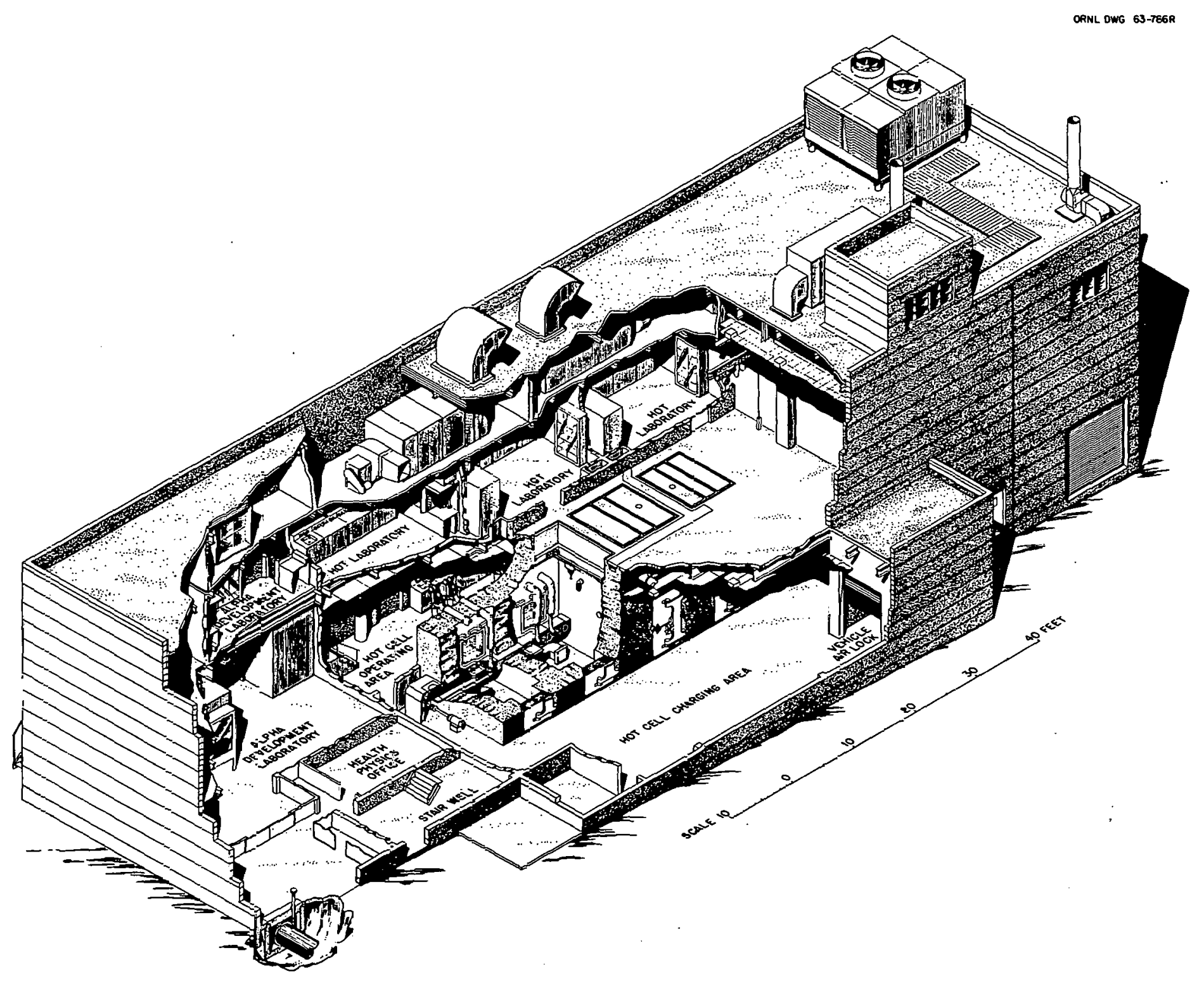

Fig. 11. Isometric section of Building 3047 . 


\section{BLDG. 3517 - FISSION PRODUCTS DEVELOPMENT LABORATORY (FPDL)}

\section{Description}

The facility contains ten chemical process cells and six manipulator cells averaging $8 \mathrm{ft}$ by $8 \mathrm{ft}$ by $14 \mathrm{ft}$ high inside and shielded by $4 \mathrm{ft}$ of concrete (Fig. 12). Three additional manipulator cells are connected to the cell blocks, and four concrete cells are located underground outside the building. Additional low-level cells house off-gas scrubbers, services, and decontamination. The cells form the primary containment, and the sealed building walls from the secondary containment barrier. All entrances to the building are via air locks.

\section{Capability}

The manipulator cells have equipment for precipitation, drying, blending, pelletization, calcination, encapsulation, and inspection. The plant is approved for an inventory of up to $10^{7} \mathrm{Ci}$ of fission products and $150 \mathrm{~g}$ of ${ }^{241} \mathrm{Am}$. The building and cell containment will have to be improved before gram quantities of plutonium and other high-alpha emitters can be handled routinely.

\section{Experience}

Numerous processing programs have been completed, including the recovery of the HRT fuel. Many beta-gamma sources have been purified and encapsulated for targets and generators.

Processing operations for the past year have been reduced to a minimum. Tentative scheduling calls for processing HAPO materials to recover ${ }^{90} \mathrm{Sr}$ and ${ }^{137} \mathrm{Cs}$ for the Hanford Waste Management program, and to fabricate three ${ }^{90} \mathrm{Sr}$ generators for Teledyne Isotopes. However, these tasks are of short duration.

The FPDL is on a surveillance budget, a status that could ultimately lead to the decommissioning of the building. 


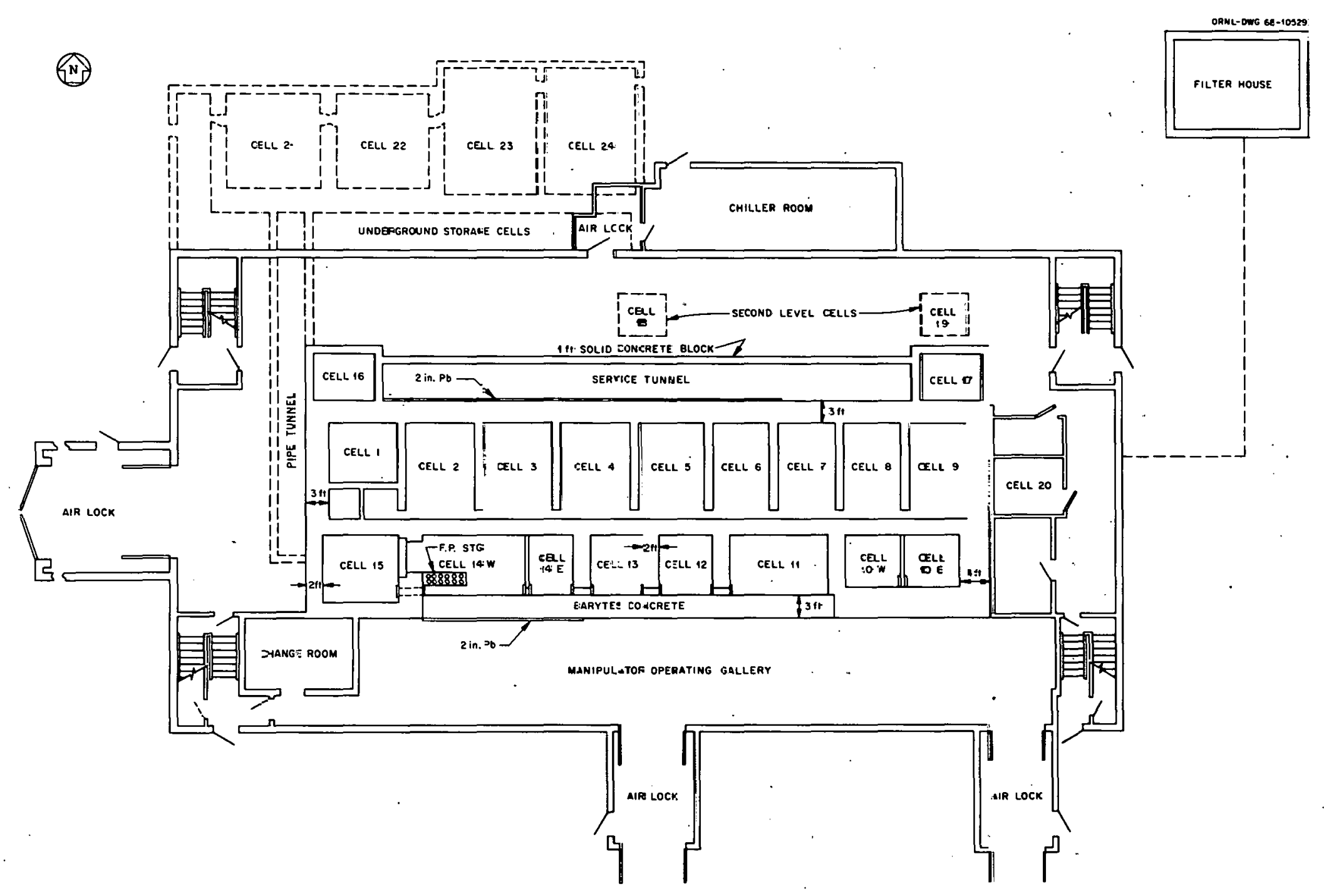

Fig. 12. Plan of Building 3517 first floor. 
11. BLDG. 3525 - HIGH-RADIATION-LEVEL EXAMINATION LABORATORY (HRLEL)

Description

The cell complex (total of $\sim 950 \mathrm{ft}^{2}$ of cell floor space) consists of three cells banks with a total of 13 work stations ( 15 viewing windows). Each station is $\sim 6 \mathrm{ft}$ by $10 \mathrm{ft}$ by $14 \mathrm{ft}$. Shielding is provided by $3 \mathrm{ft}$ of high-density concrete and lead-glass viewing windows. Each cell bank is equipped with an electromechanical manipulator and a 3-ton bridge crane; each work station is equipped with master-slave manipulators. The cells are lined with stainless steel, have a low leak rate, and have absolute filters in recirculation and exhaust systems; they are approved for high alpha-gamma work (Figs. 13 and 14).

Installed examination equipment includes a complete metallography line (saw, mounting press, grinders, polishers, etching station, two shielded metallographs, microhardness tester, and $x$-ray diffraction equipment). A shielded electron microprobe analyzer and shielded and unshielded scanning electron microscopes with nondispersive $x$-ray detection capabilities were installed recently.

Other equipment routinely available include a gamma spectrometer (GeLi detector) coupled with a 4096 channel computer analyzer, analytical balances, a laser-beam fission gas sampler, high-precision dimensional equipment, calorimetry equipment, a magnifying periscope and stereomicroscopes, and a picnometer and submersion balance for density measurements. Special equipment is available for examining microspheres. The facility has disassembly equipment (mill, hacksaw, bandsaw, and abrasive saws) and supporting photographic darkroom equipment.

\section{Capability}

The HRLEL is used for postirradiation mechanical disassembly and physical and metallurgical examination of high-alpha and gamma materials. The quantities of plutonium that can be handled are limited only by criticality considerations.

The cells are not suitable for "wet" corrosive chemistry because most of the in-cell equipment is of mild steel construction, especially the electromechanical manipulators and the overhead bridge crane. 


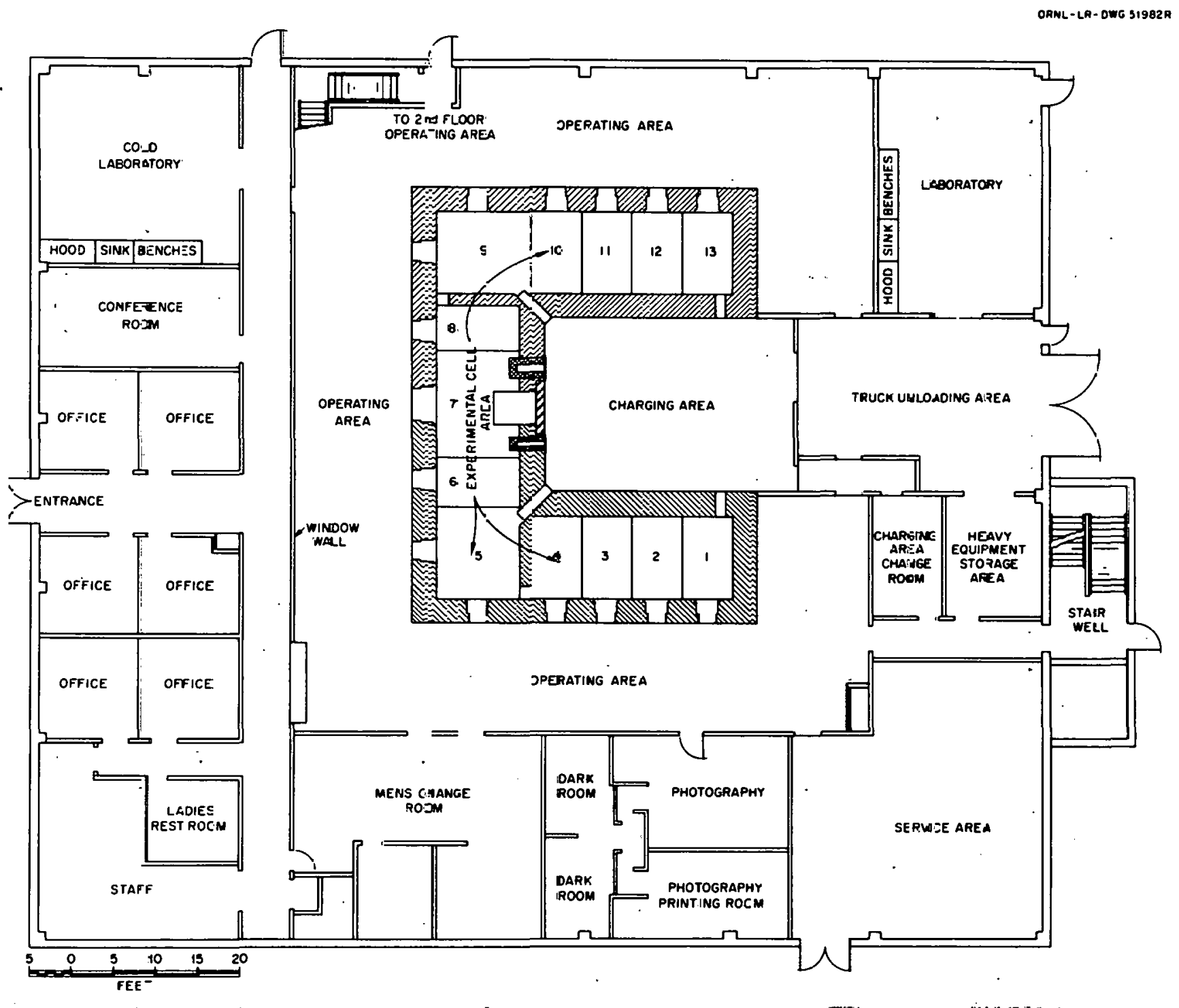

Fig. 13. First floor plan of High Radiation Level Examination Latoratary, Euịlding 35:?5. 


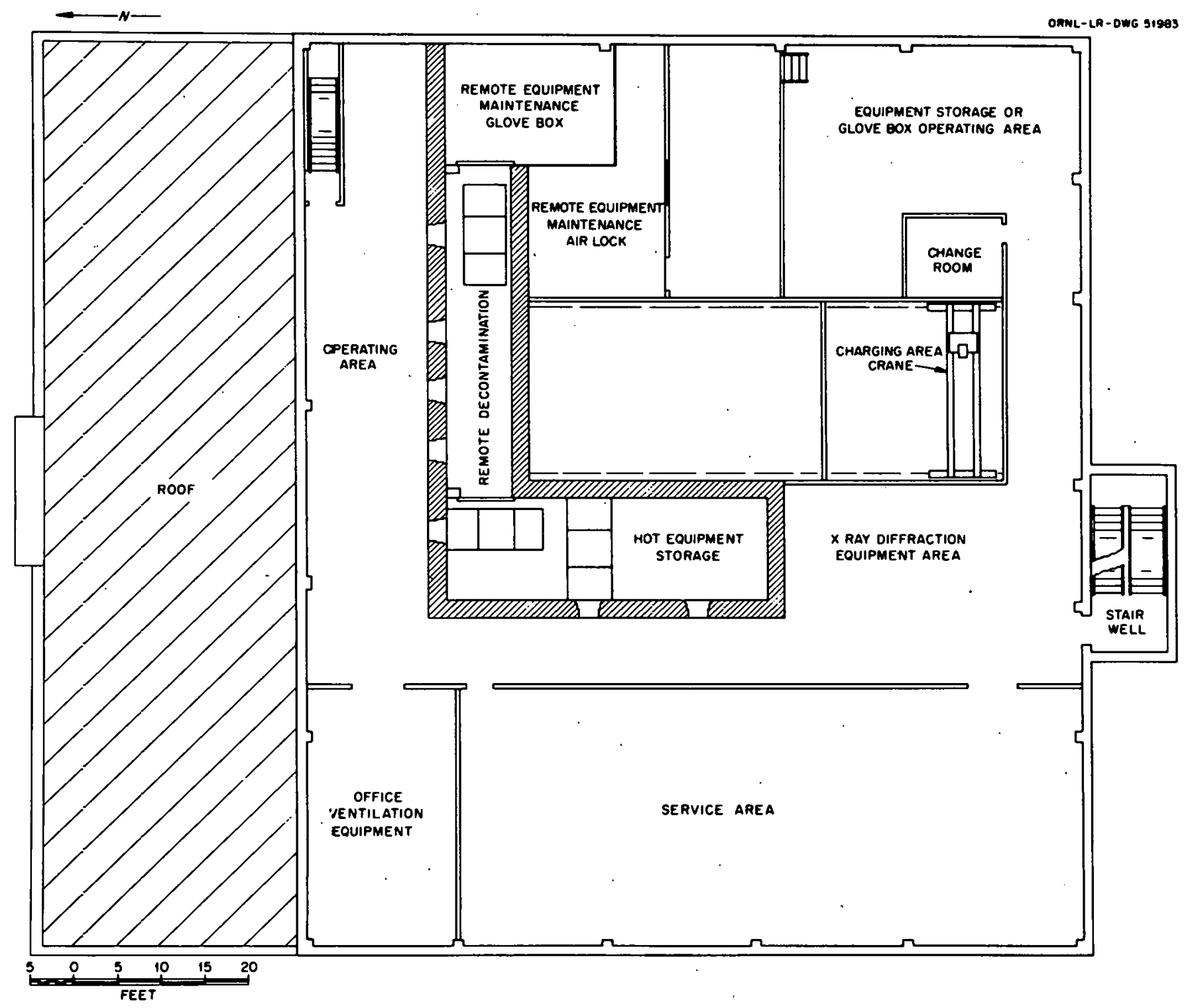

Fig. 14. Second floor plan of High Radiation Level Examination Laboratory, Building 3525. 
Although HRLEL has commitments to some customers through 1979, they would welcome additional work of the "dry" type, which they are equipped to handle.

\section{Experience}

The following are routinely examined at HRLEL: HFIR, ORR, APPR, and PM-1 fuel elements; prototype GCBR- and LMFBR-type fuel pins; refractory metals and their oxides, nitrides, and silicides and ferrous and nonferrous structural materials; nuclear fuels including $\mathrm{UO}_{2}, \mathrm{ThO}_{2},(U, \mathrm{Th}) \mathrm{O}_{2}$, $(U, P u) O_{2}, U C_{2}, T h C_{2},(U, T h) C_{2}$, and other fuels. The examinations include dimensional checks, heat generation measurements, gamma scan, fission gas sampling, sectioning, and metallography.

\section{BLDG. 4501 - HOT CELLS}

\section{Description}

The facility cell bank is a square array of four stainless steellined cells with 3-ft walls of barytes concrete (Fig. 15). Each cell has two viewing windows of cerium-lead glass, eight 6-in.-diam viewing ports filled with zinc bromide solution, and seven penetrations for periscopes. All cells have a walk-in-door, a sampling window, and an access door opening into a buffer or contamination zone on the east and west sides. Removable concrete ceiling plugs provide access into the cells from the crane bay area. The exit air is HEPA-filtered in the basement before entering the main filter banks at the 3039 stack area.

The operating face of each cell is enclosed in a separate operating room which serves as a secondary containment; the building, in turn, serves as the third or outer containment. Each cell has two Model 8 AMF manipulators, and two cells are equipped with a periscope for remote examinations and photography (Fig. 16).

\section{Capability}

Radiochemical separations research and process development can be conducted. Gram quantities of plutonium-bearing materials having a sufficiently high beta-gamma ratio can be handled, although each application 
(Cross-Hatched Areas Radiation Zones)

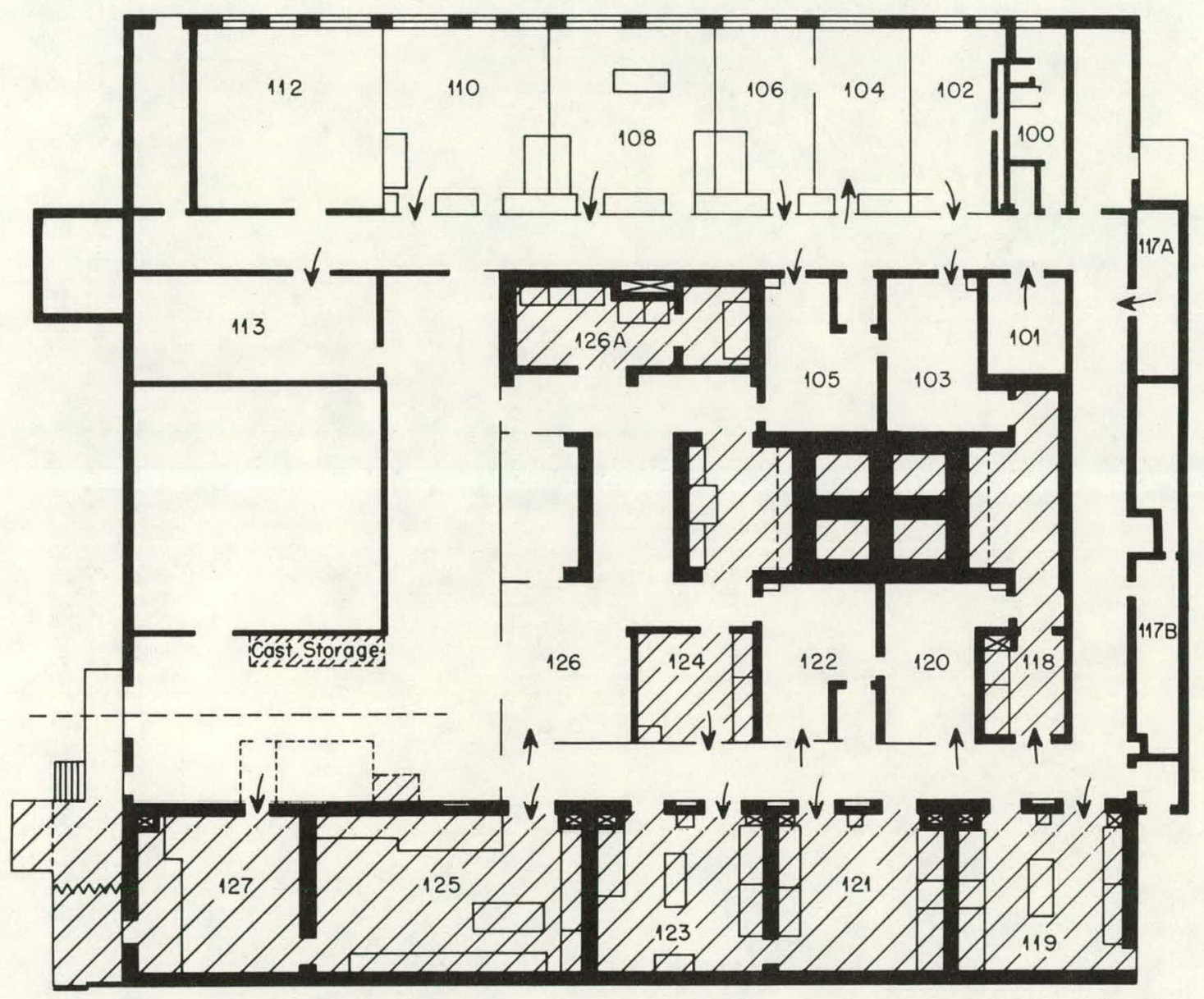

Fig. 15. First floor plan of Building 4501. 


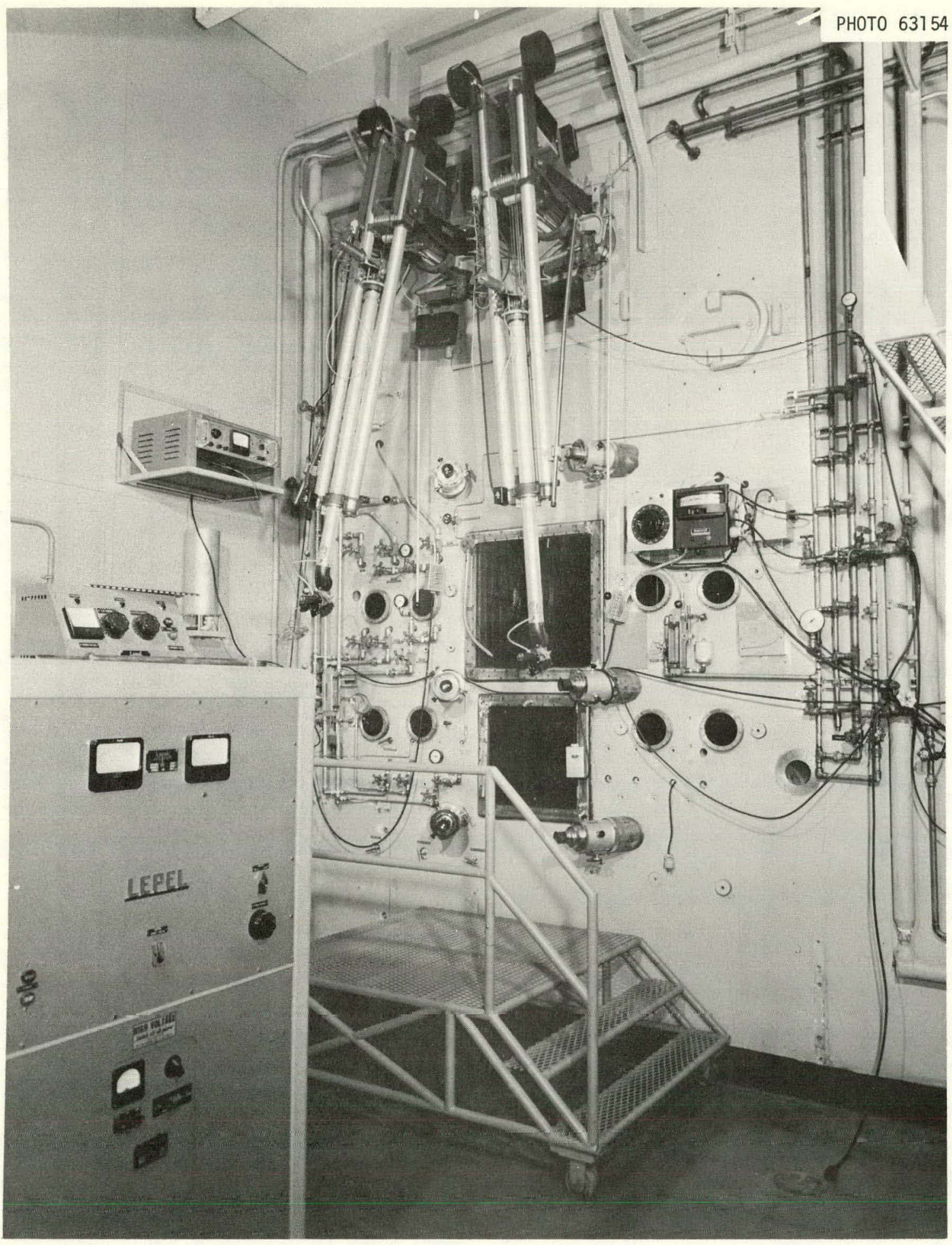

Fig. 16. Building 4501 - hot cell with periscopes. 
must be reviewed and approved by the ROC because present cell containment does not meet criteria for handling large quantities of alpha emitters. The cutting of irradiated plutonium-bearing fuels is no longer permitted.

Experience

Radiochemical separations of ${ }^{135} \mathrm{Xe},{ }^{99} \mathrm{Tc}$, and ${ }^{237} \mathrm{~Np}$ have been conducted in the cells, as have LWR safety fission product release studies. Other studies, such as reactor fuel preparation and molten salt experiments, have been conducted.

Tritium work is being done in Cell $A$; prior to this, charcoal ignition studies were done, and the equipment is still intact. In Cell B, LWR transport studies are being conducted. Liquid-Metal Fast Breeder Reactor aerosol research is being done in Cell C. The HTGR graphite specimens are cut in Cell $D$ before transferring the material to the HRLAF for examination and analyses.

13. BLDG. 4507 - HIGH RADIATION-LEVEL CHEMICAL DEVELOPMENT LABORATORY Description

The facility has four cells, aligned in a row, shielded by $4 \mathrm{ft}$ of high-density concrete (Fig. 17). Each cell is $6 \mathrm{ft}$ wide, $11 \mathrm{ft}$ high, and $10 \mathrm{ft}$ deep and has a lead glass window filled with mineral oil. A removable door at the rear provides access to the cell. interior, and removable roof plugs permit the installation or removal of equipment with the gantry crane in the penthouse above the cell bank. The building and cells meet all containment requirements for handling large quantities of high-alpha emitters. Three cells are equipped with medium-duty manipulators, and one cell is equipped with heavy-duty manipulators.

\section{Capability}

Adequate containment and approval to handle multigram quantities of transuranic and transplutonic isotopes permit small-scale fuel processing demonstrations. The quantity of plutonium is limited only by criticality considerations.

The relative ease with which experimental equipment can be removed or replaced gives these cells a versatility that has been demonstrated by the many types of development work that have been conducted in them. 


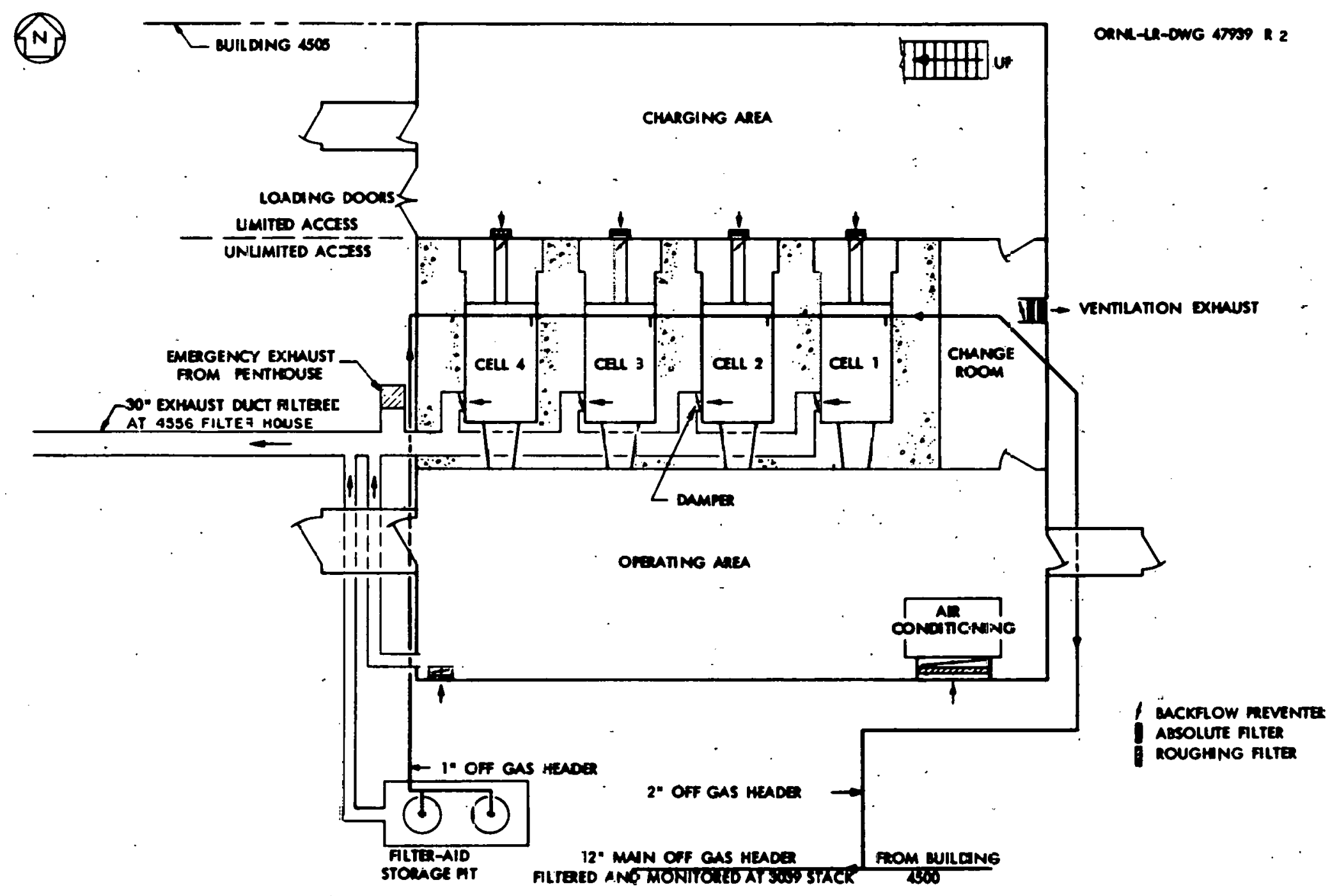

Fig. 17. Plan of Building 4507 first floor. 


\section{Experience}

Multigram amounts of ${ }^{238} \mathrm{Pu}$ have been separated in small-scale reprocessing equipment. Many dissolution experiments on solid fuel elements, including highly irradiated plutonium-aluminum alloy elements, have been conducted in this facility. Several hundred grams of plutonium have been purified by anion exchange. Gram quantities of the transuranic isotopes were processed during transuranium development work in Cells 3 and 4.

Presently, HTGR experiments are being conducted in Cells 1 and 4, and LMFBR/LWR experiments are under way in Cells 2 and 3.

\section{BLDG. 7920 - TRANSURANIUM PROCESSING PLANT (TRU) Description}

The Transuranium Processing Plant has an integrated hot-cell complex that contains four cells for the chemical processing of irradiated HFIR targets, three cells for fabrication and inspection of HFIR targets, and two cells for high-level analytical chemistry work (Figs. 18 and 19). The cells are arranged in a line and have $54 \mathrm{in}$. of high-density concrete for shielding from gamma radiation and neutrons. Each cell has a lead glass, oil-filled view window, and two master-slave manipulators. The cells are $7 \mathrm{ft}$ by $7 \mathrm{ft}$ by $81 / 2 \mathrm{ft}$, and removable top plugs provide access to the cells. Behind and below each cell is a floodable pit where storage tanks are located.

The primary containment of the cell bank and the secondary containment of the building comply with all ORNL criteria. Equipment for removing radioactive iodine from the Iodox dissolver solutions is being installed, along with a new system of charcoal adsorbers that will provide independent backup for the present vessel off-gas system.

\section{Capability}

The chemical processing system consists of head-end solution and feed adjustment equipment, a centrifuge, two cycles of solvent extraction, and an ion exchange cleanup cycle. The equipment is sized to handle 25-liter batches at feed rates of 1 to 2 liters per hour, is constructed of tantalum and zircaloy-2, and can handle nitric or hydrochloric acid flowsheets. 


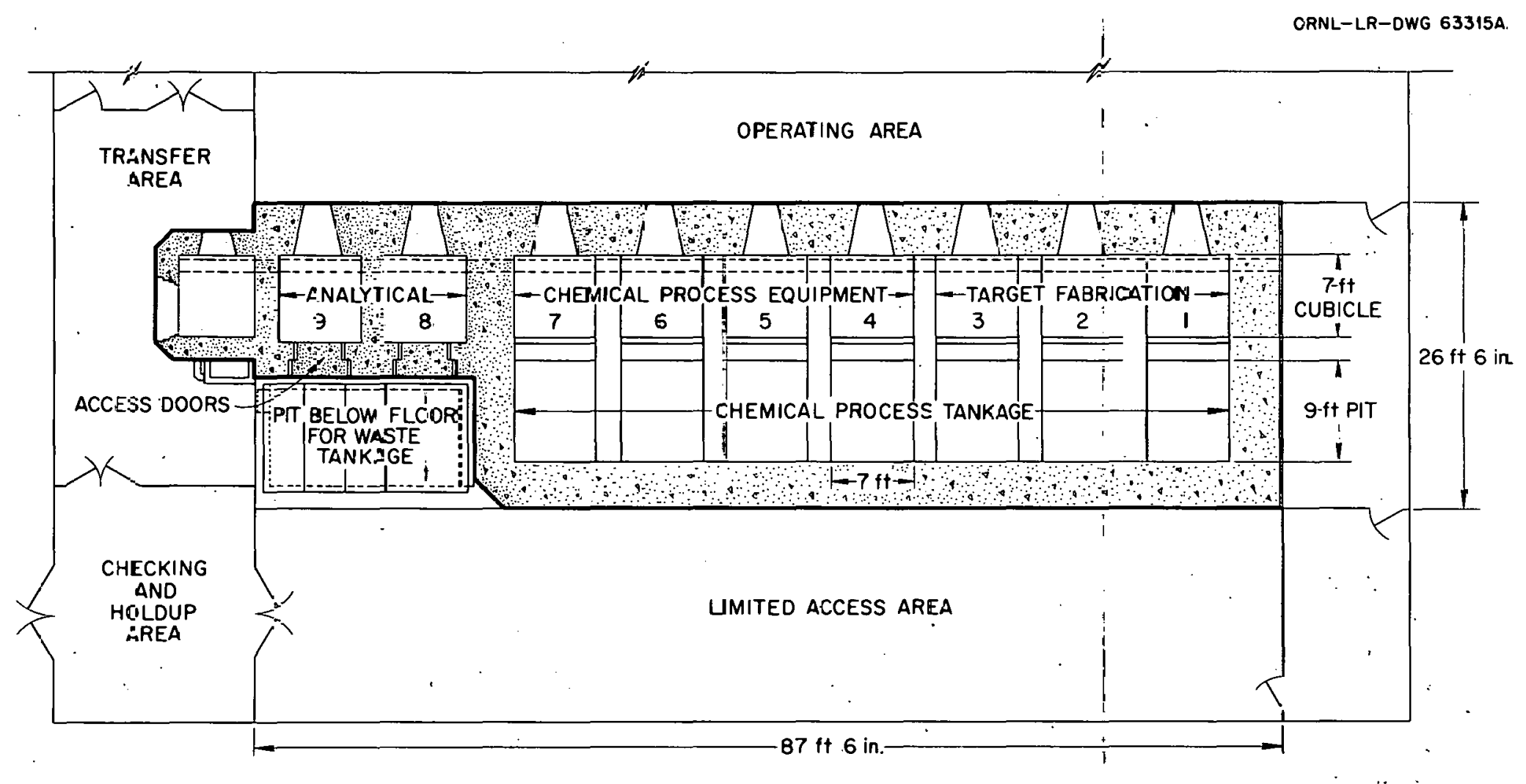

Fig. IE. Plan of Building. 7920 hot cell bark. 


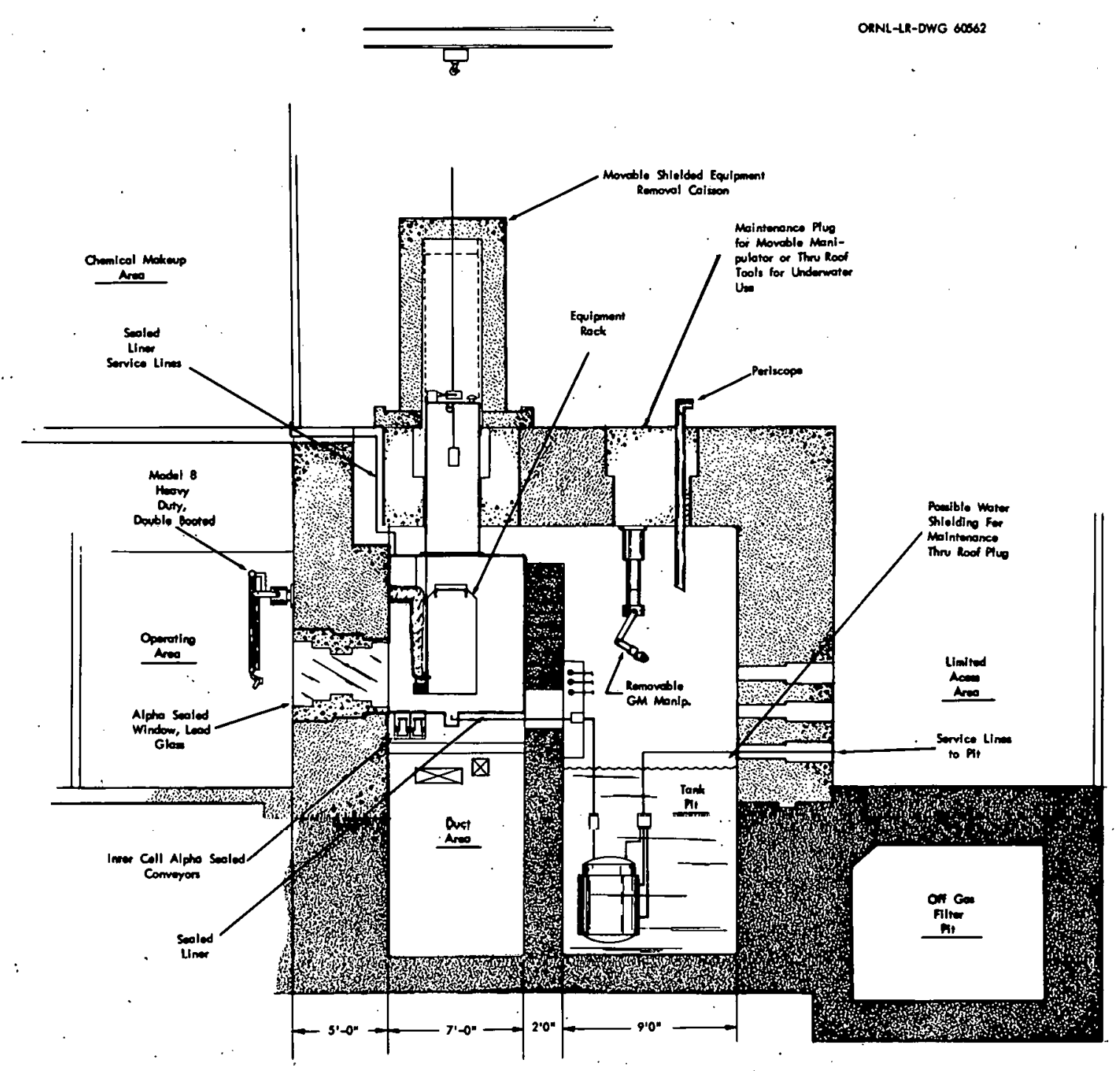

Fig. 19. Cross section of Building 7920 hot cell bank. 
However, reagents containing fluoride ions, even in small concentrations (10-25 ppm), cannot be used because of the corrosive effect on the zircaloy-2. Also, caustic solutions are barred from the tantalum equipment for the same reason. The three refabrication cells are equipped for remote encapsulation and inspection of HFIR targets.

\section{Experience}

Targets of ${ }^{242} \mathrm{Pu},{ }^{243} \mathrm{Am}$, and curium isotopes have been fabricated for neutron radiation in the HFIR and have then been chemically reprocessed to recover the transcurium isotopes $\left({ }^{244} \mathrm{Cm},{ }^{248} \mathrm{Cm},{ }^{249} \mathrm{Bk},{ }^{252} \mathrm{Cf},{ }^{254} \mathrm{Cf}\right)$.

Two processing campaigns on HrlK-irradiated targets and the fabrlcation of 12 HFIR targets are scheduled for 1977. A facility for the development of a Purex flowsheet to process spent LWR fuels is being designed.

\section{BLDG. 7930 - THORIUM-URANIUM FUEL CYCLE} DEVELOPMENT FACILITY (TURF)

\section{Description}

The facility is an irregularly shaped three-story building with a partial basement (Fig. 20). A high bay area over the cell roof providcs space for the entry of cell services, the handling of fuel shipping casks and other heavy objects with a 50 -ton crane, and cell access. The building serves as a secondary containment shell around the hermetically sealed cells.

The cell complex includes four process cells and a decontamination cell shielded by the equivalent of $b 1 / 2 \mathrm{ft}$ of concrete, a lightly shielded cell for equipment storage and a large, unshielded, gloved enclosure for equipment maintenance (Fig. 21). Each of two process cells is provided with a remotely operable overhead crane and an electromechanical manipulator system for installation, maintenance, and removal of equipment. Contact maintenance procedures will be used in the other four shielded cells; however, one of the cells can be converted to remote maintenance by removing part of the wall between it and the adjacent cell. 


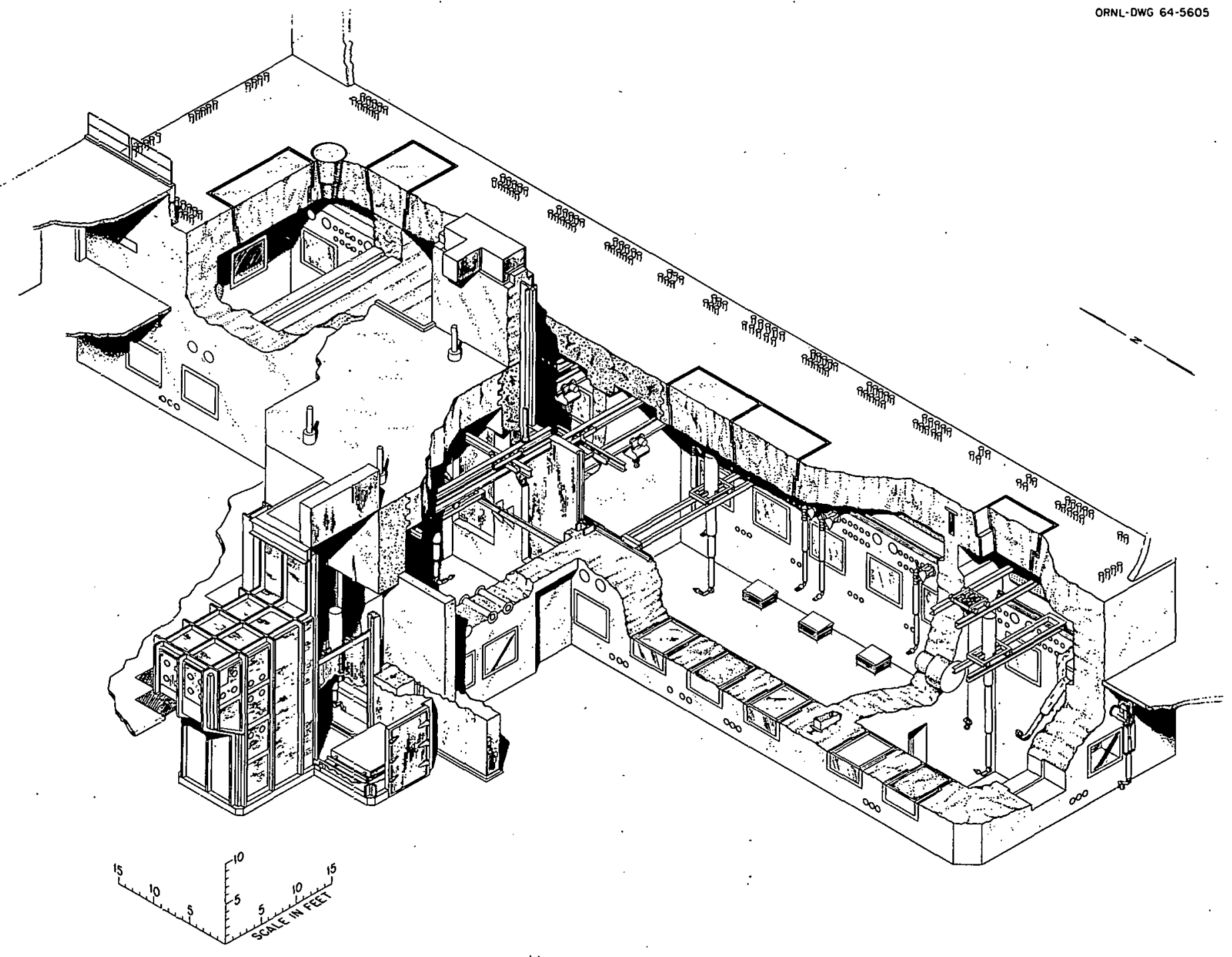

Fig. 20. Isometric section of Building 7930 . 


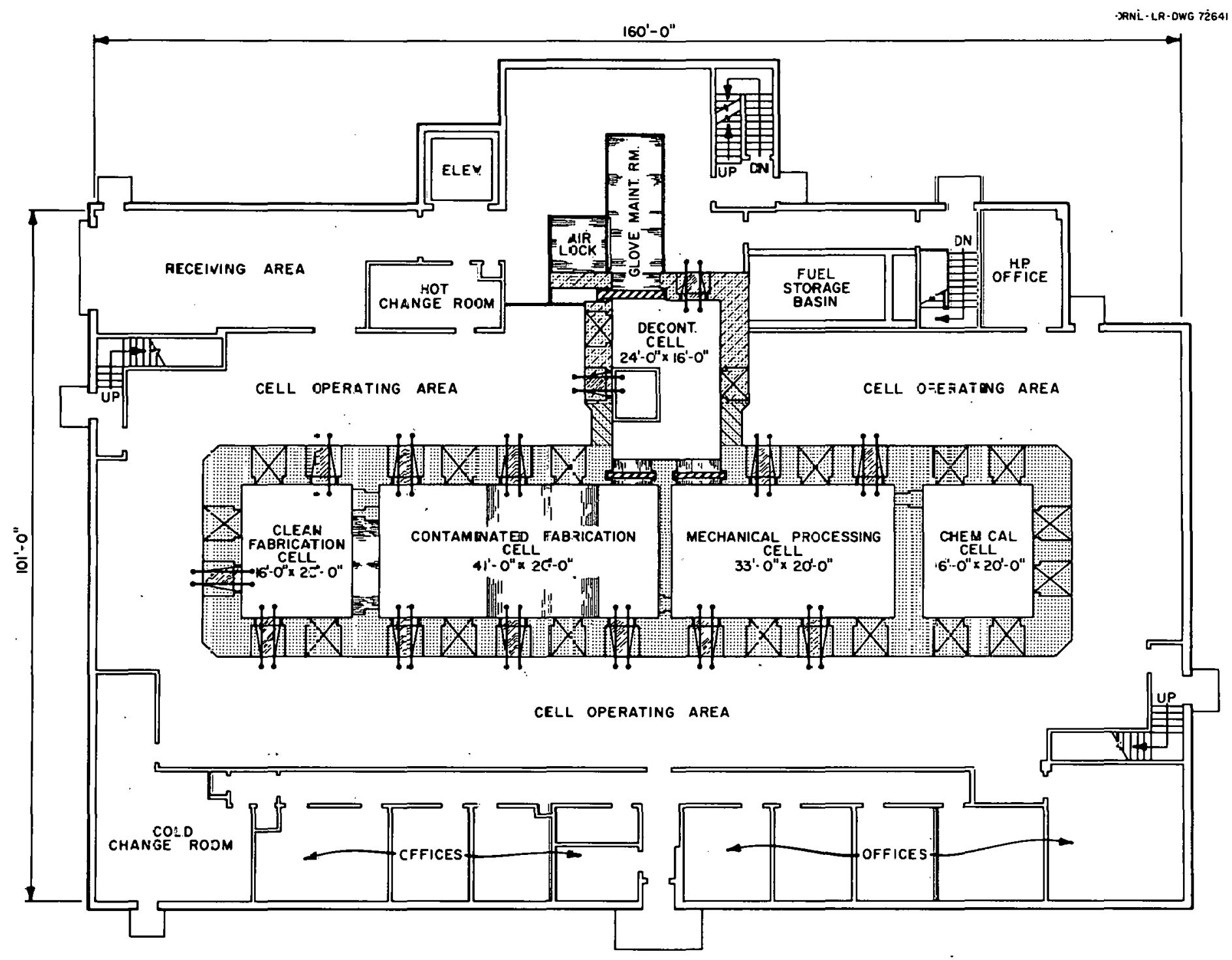

Fig. 21. First iloor plan of Building 7930. 


\section{Capability}

The facility is designed for engineering-scale development of fuel recycle schemes at high levels of alpha and gamma radiation. It includes provisions for the installation of equipment for head-end processing, chemical purification, fuel reconstitution, fuel fabrication involving alpha hazardous materials, and fuel fabrication operations involving clad materials with high gamma-ray emission. Single rods up to $12 \mathrm{ft}$ long and rod assemblies can be remotely produced for evaluation and testing. Processes that require inert atmosphere protection can be accommodated. The quantity of plutonium that can be handled is limited only by criticality considerations.

\section{Experience}

Experimental research for the development of a MSRE ${ }^{233} \mathrm{U}$ fuel salt process was conducted in the facility. Milligram amounts of ${ }^{252} \mathrm{Cf}$ have been purified by a high pressure, chromatographic ion-exchange technique for the fabrication of californium neutron sources.

Some HTGR work is being conducted in Cell B, and the Chemical Technology Division (СТD) is doing californium work in Cell G. Cells C, D, and $E$ are not in use at this time. However, all cells will be stripped and, in some cases, enlarged for the Hot Engineering Test portion of the HTGR Fuel Cycle Program. The Program will utilize the entire facility, and no space for future CTD work will be available. 


\section{THIS PAGE \\ WAS INTENTIONALLY \\ LEFT BLANK}


ORNL/TM-5971

\title{
Internal Distribution
}

\author{
1. R. E. Brooksbank \\ 2. W. D. Burch \\ 3. J. H. Coobs \\ 4. J. A. Cox \\ 5. F. L. Culler \\ 6. D. E. Ferguson \\ 7. E. L. Gaden, Jr. (Consultant) \\ 8. C. H. Ice (Consultant) \\ 9. E. M. King \\ 10. L. J. King \\ 11. M. H. Lloyd \\ 12. A. L. Lotts \\ 13. A. P. Malinauskas \\ 14. L. E. McNeese \\ 15. J. R. Parrott \\ 16. H. Postma \\ 17. M. E. Ramsey \\ 18. R. B. Richards (Consultant) \\ 19. R. W. Schaich \\ 20. C. D. Scott \\ 21. D. B. Trauger \\ 22. B. L. Vondra \\ 23. J. R. Weir \\ 24-28. W. R. Whitson \\ 29. R. G. Wymer \\ 30. A. Zucker \\ 31-32. Laboratory Records \\ 33. Laboratory Records-RC \\ 34-35. Central Research Library \\ 36. Document Reference Section \\ 37. ORNL Patent Section \\ External Distribution
}

38-64. Technical Information Center, Oak Ridge, TN 37830

65. Research and Technical Support Division, ERDA-ORO, P. 0. Box E, Oak Ridge, TN 37830 